\title{
Mutations in RHOT1 Disrupt Endoplasmic Reticulum-Mitochondria Contact Sites Interfering with Calcium Homeostasis and Mitochondrial Dynamics in Parkinson's Disease
}

Dajana Grossmann,, Clara Berenguer-Escuder, ${ }^{1}$ Marie Estelle Bellet, ${ }^{1}$ David Scheibner, ${ }^{2}$ Jill Bohler, Francois Massart, ${ }^{1}$ Doron Rapaport, ${ }^{3}$ Alexander Skupin,, ${ }^{1,4}$ Aymeric Fouquier d'Hérouël, ${ }^{1}$ Manu Sharma, ${ }^{5}$ Jenny Ghelfi, Aleksandar Raković, ${ }^{6}$ Peter Lichtner, ${ }^{1}$ Paul Antony, ${ }^{1}$ Enrico Glaab,, Patrick May, Kai Stefan Dimmer, ${ }^{3}$ Julia Catherine Fitzgerald, ${ }^{2}$ Anne Grünewald, ${ }^{1,6, *}$ and Rejko Krüger, ${ }^{1,2,8,{ }^{*}}$

\begin{abstract}
Aims: The outer mitochondrial membrane protein Miro1 is a crucial player in mitochondrial dynamics and calcium homeostasis. Recent evidence indicated that Miro1 mediates calcium-induced mitochondrial shape transition, which is a prerequisite for the initiation of mitophagy. Moreover, altered Miro1 protein levels have emerged as a shared feature of monogenic and sporadic Parkinson's disease (PD), but, so far, no diseaseassociated variants in $R H O T 1$ have been identified. Here, we aim to explore the genetic and functional contribution of RHOT1 mutations to PD in patient-derived cellular models.

Results: For the first time, we describe heterozygous RHOT1 mutations in two PD patients (het c.815G $>\mathrm{A}$; het c.1348C $>$ T) and identified mitochondrial phenotypes with reduced mitochondrial mass in patient fibroblasts. Both mutations led to decreased endoplasmic reticulum-mitochondrial contact sites and calcium dyshomeostasis. As a consequence, energy metabolism was impaired, which in turn caused increased mitophagy.

Innovation and Conclusion: Our study provides functional evidence that ROTHI is a genetic risk factor for PD, further implicating Miro1 in calcium homeostasis and mitochondrial quality control. Antioxid. Redox Signal. $31,1213-1234$.
\end{abstract}

Keywords: Miro1, mitochondria, calcium, ER-mitochondria contact site, Parkinson's disease, patient fibroblasts

\footnotetext{
${ }^{1}$ Luxembourg Centre for Systems Biomedicine (LCSB), University of Luxembourg, Esch-sur-Alzette, Luxembourg.

${ }^{2}$ Department of Neurodegenerative Diseases, Center of Neurology and Hertie-Institute for Clinical Brain Research, University of Tübingen, Tübingen, Germany.

${ }^{3}$ Interfaculty Institute of Biochemistry (IFIB), University of Tübingen, Tübingen, Germany.

${ }^{4}$ National Biomedical Computation Resource, University of California San Diego, La Jolla, California.

${ }^{5}$ Centre for Genetic Epidemiology, Institute for Clinical Epidemiology and Applied Biometry, University of Tübingen, Tübingen, Germany.

${ }^{6}$ Institute of Neurogenetics, University of Lübeck, Lübeck, Germany.

${ }^{7}$ Institute of Human Genetics, Helmholtz Zentrum München GmbH, Neuherberg, Germany.

${ }^{8}$ Parkinson Research Clinic, Centre Hospitalier de Luxembourg (CHL), Luxembourg, Luxembourg.

*Both these authors share senior authorship.

(C) Dajana Grossmann et al. 2019; Published by Mary Ann Liebert, Inc. This Open Access article is distributed under the terms of the Creative Commons License (http://creativecommons.org/licenses/by/4.0), which permits unrestricted use, distribution, and reproduction in any medium, provided the original work is properly cited.
} 


\section{Innovation}

Miro1 is a crucial player in different pathways involved in the pathogenesis of Parkinson's disease (PD), for example, functional impaired of Miro1 was previously described as a shared feature of defective mitophagy in cellular models of monogenic and sporadic PD. Although RHOT1 was assumed to be a potential risk factor in PD over several years, no study could show pathogenic mutations. Our results provide first genetic and functional evidence linking disease-associated variants in RHOT1 with mitochondrial dysfunction in PD, including impaired endoplasmic reticulum-mitochondrial tethering and calcium homeostasis. Thus, our study moves Miro1 more into the focus of potential therapeutic strategies for PD.

\section{Introduction}

$\mathbf{T}$ HE MITOCHONDRIAL RHO GTPase Miro1 has primarily been studied with respect to its function as an adaptor protein for mitochondrial transport $(48,49)$, yet far less is known about the involvement of Miro1 in other processes crucial for maintaining mitochondrial homeostasis, such as mitochondrial calcium handling (9), mitochondrial quality control $(49,50)$, and overall mitochondrial homeostasis (46). Miro1 contains an N-terminal GTPase domain, followed by two calcium-binding EF-hand domains, a second C-terminal GTPase domain, and the C-terminal transmembrane domain. The GTPase domains are involved in the control of mitochondrial movement (30) and in the regulation of mitochondrial calcium uptake (37) via the mitochondrial calcium uniporter (MCU) (9). The calcium binding motifs of Miro1 are suggested to ensure the proper spatial arrangement of mitochondrial networks $(31,42,48)$ as well as mitochondrial calcium uptake (9).

An initial link between Miro1 and Parkinson's disease (PD) arose from the identification of Mirol as a target of the PD-associated kinase PINK1 (PARK6) in a mitochondrial quality control pathway (50). Mitochondrial arrest is an important initial step required to isolate dysfunctional mitochondria and to prevent their fusion with healthy mitochondria. As a consequence, immobile fragmented mitochondria are primed for autophagosomal uptake and lysosomal degradation (50). Moreover, in monogenic and sporadic PD, an impairment of Miro1 degradation and mitochondrial dynamics was identified as a central component in neurodegeneration (16).

A recent study in embryonic fibroblasts from Miro1-mutant mice provided evidence for a link between the calciumsensing function of Miro1 and mitochondrial shape transition (MiST), which is a crucial prerequisite for subsequent mitophagy (31).

Here, we report the identification of mutations in RHOT1, the gene encoding Miro1, in PD patients and describe their pathogenic role in the maintenance of endoplasmic reticulum (ER)-mitochondria contact sites, cellular calcium homeostasis, and energy metabolism. Our phenotypic characterization in patient-derived cells points at the multifaceted roles of Miro1 at the outer mitochondrial membrane and highlights the significance of the protein for calcium homeostasis and mitochondrial impairment related to the pathogenesis of PD.

\section{Results \\ Identification of R272Q and R450C RHOT1 variants in $P D$ patients}

Since several studies suggested that variants in $R H O T 1$ may confer risk to develop PD $(2,16,49)$, we performed a comprehensive genetic screening for mutations in RHOT1 in PD patients. In a German cohort of 752 PD patients and a total of 374 healthy controls, we identified 2 female patients carrying a heterozygous mutation $\mathrm{c} .815 \mathrm{G}>\mathrm{A}$ or $\mathrm{c} .1348 \mathrm{C}>\mathrm{T}$ in RHOT1 (NM_001033568), leading to the amino acid exchanges R272Q and R450C, respectively (Fig. 1A). The amino acid R272 is positioned within the ligand mimic motif of the first EF-hand domain (20) and the residue R450 lies within the C-terminal GTPase domain (Fig. 1A). According to the homology model of the human Mirol protein, the affected amino acids are exposed to the cytosol on the protein surface (Fig. 1C). Different in silico prediction methods revealed a high likelihood for both mutations to have pathogenic effects (Fig. 1D). Medical records of the fathers of both index patients revealed an unclassified tremor (Fig. 1B). Due to the typical late onset and family history for motor symptoms, both patients were also tested for GBA and LRRK2

FIG. 1. Identification of $R 272 Q$ and $R 450 C$ RHOT1 variants in PD patients. (A) Table of point mutations identified in RHOT1 in two PD patients and location of both mutations within the protein structure of Miro1. Miro1 consists of an Nterminal GTPase domain, followed by two EF-hand domains, a C-terminal GTPase domain, and a TMD. (B) Pedigree of PD patients with heterozygous point mutations in RHOT1. Individuals displaying motor symptoms are highlighted in gray, arrows pointing to PD patients of whom fibroblasts were obtained for the present study. (C) Left panel: homology model of WT human Miro1, covering the 3D protein structure of the both EF-hand domains and the C-terminal GTPase domain. The WT amino acids R272 and R450 are highlighted in circles. Right panel: homology model of mutant Miro1 with both mutant amino acids R272Q and R450C highlighted in circles. (D) In silico prediction of pathogenic effects of both Miro1 variants. $\mathrm{d} / \mathrm{h}$, deleterious/highly functional; $\mathrm{p} / \mathrm{m}$, probably damaging/medium functional; $\mathrm{t}$, tolerant. (E) Genotyping and data mining of a set of PD and control databases to identify additional carriers of the RHOT1 mutations. The whole-exome server on neurodegenerative disease, containing 1500 genomes, was searched for additional carriers of the R272Q and R450C variants. Additionally, 1900 samples (662 control individuals from the KORA cohort and 1238 German PD patients) (51) were genotyped to confirm our previous findings. No additional carrier of the R272Q or R450C variants was identified. (F) Burden analysis of variants in RHOT1 from the gnomAD database. LoF variants were defined as single nucleotide exchanges causing nonsense splice acceptor or splice donor variants. Z-score =calculated from expected variant counts divided by observed variant counts. pLI scores close to 1 indicate a high intolerance to LoF variants. 3D, three-dimensional; LoF, loss-of-function; PD, Parkinson's disease; pLI, probability of being LoF intolerant; TMD, transmembrane domain; WT, wild type. Color images are available online. 


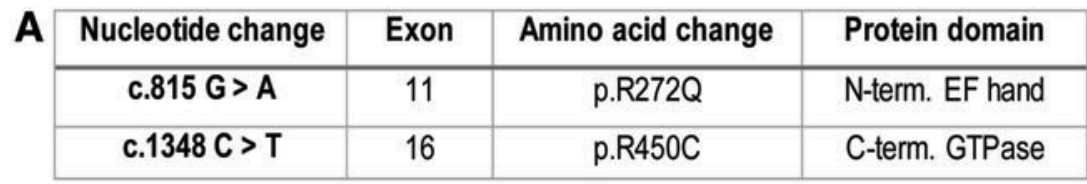
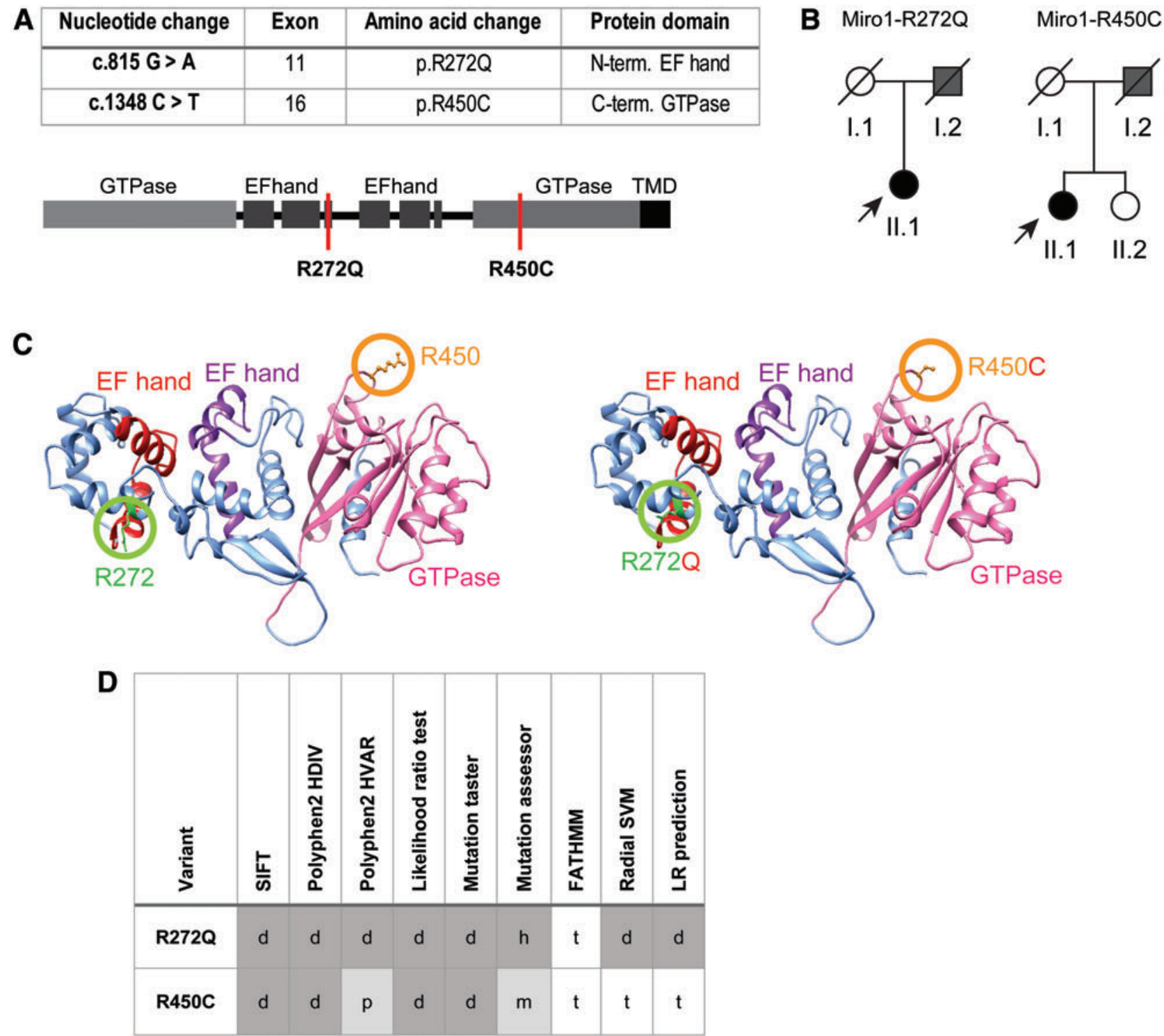

\begin{tabular}{|c|c|c|c|}
\hline Data origin & Sample size & Type of analysis & Variants \\
\hline $\begin{array}{c}\text { Whole Exome Server on neurodegenerative } \\
\text { diseases (Tübingen, Germany) }\end{array}$ & 1500 genomes & database & - \\
\hline $\begin{array}{c}662 \text { healthy controls (KORA cohort) } \\
1238 \text { German PD patients }\end{array}$ & 1900 samples & genotyping & - \\
\hline
\end{tabular}

\begin{tabular}{|c|c|c|c|}
\hline Constraint from ExAc & Expected no. variants & Observed no. variants & Constraint Metric \\
\hline Synonymous & 124 & 101 & $\mathrm{z}=1.62$ \\
\hline Missense & 362.3 & 230 & $\mathrm{z}=2.47$ \\
\hline Loss of function & 44.9 & 9 & $\mathrm{pLI}=0.8$ \\
\hline
\end{tabular}


mutations. This analysis excluded the GBA N370S and L444P and the LRRK2 G2019S and I2020T mutations by Sanger sequencing in both patients.

To identify additional carriers of the herein described RHOT1 variants, we next searched a whole-exome database on neurodegenerative diseases containing 1500 patient genomes. This approach revealed no additional carrier of R272Q or R450C mutations. Additional genotyping of 1238 German PD patients (51) and 662 healthy controls (KORA cohort) provided no further carriers of the R272Q or R450C mutation (Fig. 1E).

Using the gnomAD browser to assess the genetic burden of RHOT1 mutations in the general population, we found a lower amount of missense mutations than expected (missense $\mathrm{z}$-score $=2.47$ ) and a constraint for loss-of-function $(\mathrm{LoF})$ mutations (observed/expected $[\mathrm{o} / \mathrm{e}]$ score $=0.2$; probability of being LoF intolerant (pLI) score $=0.8$; Fig. 1F), which further supports a potential pathogenic role of damaging mutations in RHOT1.

In the gnomAD database, we found no additional carrier of the R272Q variant, but three carriers of the R450C variant (allele frequency 1.06e-5). Two of these individuals are of European ancestry and the third individual of East Asian origin. All carriers of the R450C variant are heterozygous and their age was between 30 and 35 years. As our patients carrying Miro1 mutations presented with typical late-onset PD, it cannot be excluded that these individuals will develop PD later in life.

From these results, we conclude that damaging mutations in RHOT1 are a rare event and suggest that mutations may contribute to the development of PD.

\section{Reduced calcium buffering capacity in Miro1-mutant fibroblasts}

One important function of Miro1 is the maintenance of mitochondrial calcium homeostasis $(9,37)$, which is regulated by the calcium-binding EF-hand motifs and the C- terminal GTPase domain (37). To assess the effects of mutant Miro1 on calcium homeostasis, we used the cytosolic calcium indicator Fluo4-AM. Cells were treated with thapsigargin (an inhibitor of the SERCA pumps) (43), which prevents calcium buffering by the ER (Fig. 2A) and causes an increase of cytosolic calcium by depletion of ER calcium stores (34). In control cells, cytosolic calcium levels decreased within $5 \mathrm{~min}$, whereas in Miro1-R272Q and in Miro1-R450C fibroblasts, the cytosolic calcium content remained increased (Fig. 2B, C).

The alteration of calcium handling was also reflected by significantly increased time constants of exponential decay, calculated from the calcium response curves after treatment with thapsigargin (Fig. 2C), in both Miro1-mutant fibroblast lines compared with controls (Fig. 2D). To distinguish whether the altered calcium profiles in mutant fibroblasts were due to impaired mitochondrial calcium buffering or a reduced calcium release across the plasma membrane, we next treated the cells with Ru360, an inhibitor of the MCU (9, 18,44 ), alone or in combination with thapsigargin (Fig. 2E, $\mathrm{G})$. Blocking of the MCU after thapsigargin treatment led to a reduced buffering capacity of cytosolic calcium in mutant and control cells (Fig. 2E).

This observation was confirmed by calculation of the linear regression of the calcium response to concomitant thapsigargin and Ru360 treatment. The slopes of the respective linear regressions were statistically not different between control and mutant fibroblasts (Fig. 2F), indicating a disruption of the calcium buffering capacity when mitochondrial calcium uptake was blocked by Ru360. These results suggest that the reduced capacity of Miro1 mutant fibroblasts to buffer cytosolic calcium is due to impaired mitochondrial buffering.

This hypothesis was further strengthened by data resulting from the analysis of calcium-induced MiST, a mechanism that was recently identified as a prerequisite of mitophagy and that is dependent on the ability of Miro1 to regulate calcium homeostasis (31). Fibroblasts were stained with MitoTracker ${ }^{\circledR}$ Green FM and treated with the calcium

FIG. 2. Reduced calcium buffering capacity in Miro1-mutant fibroblasts. (A) Overview of treatments with thapsigargin, ionomycin, and Ru360 for calcium imaging. Thapsigargin inhibits calcium uptake of the ER by the SERCA pumps, which leads to increase of cytosolic calcium levels by depletion of ER calcium stores. Ionomycin increases the levels of cytosolic calcium by activation of G-protein-coupled receptors in the plasma membrane. Ru360 is an inhibitor of the MCU. (B) Immortalized fibroblasts were loaded with Fluo4-AM (green) for live cell imaging. Cells were imaged under baseline condition for $2 \mathrm{~min}$. After addition of $1 \mu M$ thapsigargin, imaging was continued for $10 \mathrm{~min}$ with a $2 \mathrm{~s}$ interval. Images were acquired using a $25 \times$ objective; scale bars indicate $50 \mu \mathrm{m}$. (C) Quantification of calcium levels upon thapsigargin treatment from (B). Mean intensity of Fluo4-AM signal was indicated as $\left(\mathrm{F} / \mathrm{F}_{0}\right)$. Data indicated as mean $\pm \mathrm{SEM}, n=5$, with $8-20$ cells per cell line per experiment. (D) Time constant of exponential decay calculated from calcium response curves of (C). Data indicated as mean \pm SEM. Significance calculated using the Mann-Whitney test $(n=5)$. (E) Immortalized fibroblasts were stained with Fluo4-AM for live cell imaging. After $1 \mathrm{~min}$ of baseline recording, cells were treated with a combination of $10 \mu M \mathrm{Ru} 360$ and $1 \mu M$ thapsigargin, and imaging was continued for 9 min, using a $25 \times$ objective $(n=3-4)$. Data indicated as mean. (F) Slope of linear regression of calcium response curves from (E). Data indicated as mean \pm SEM. Significance calculated using the Mann-Whitney test $(n=3-4)$. (G) Immortalized fibroblasts were stained with Fluo4-AM and treated with $10 \mu M$ Ru360 during live cell imaging. Data indicated as mean $(n=3)$. (H) Microscopy images from (I) were analyzed for aspect ratios of the mitochondrial network over time using the Image J $(n=3-5)$. (I) Immortalized fibroblasts were stained with MitoTracker ${ }^{\circledR}$ Green FM and treated with $20 \mu M$ ionomycin during 20 min of live cell imaging, using a $63 \times$ objective. Scale bars indicate $20 \mu \mathrm{m}$. Representative images of the mitochondrial network in control fibroblasts, Miro1R272Q, and R450C fibroblasts. Mitochondrial masks generated with the ImageJ for the analysis of mitochondrial morphology were displayed at different time points for all cell lines. The white boxes in the microscopy images on the left highlight the sections depicted on the right, showing details of the mitochondrial network at different time points (binary images). Significance for all data calculated by the Mann-Whitney test. ${ }^{*} p \leq 0.05$. ER, endoplasmic reticulum; MCU, mitochondrial calcium uniporter; SEM, standard error of the mean. Color images are available online. 

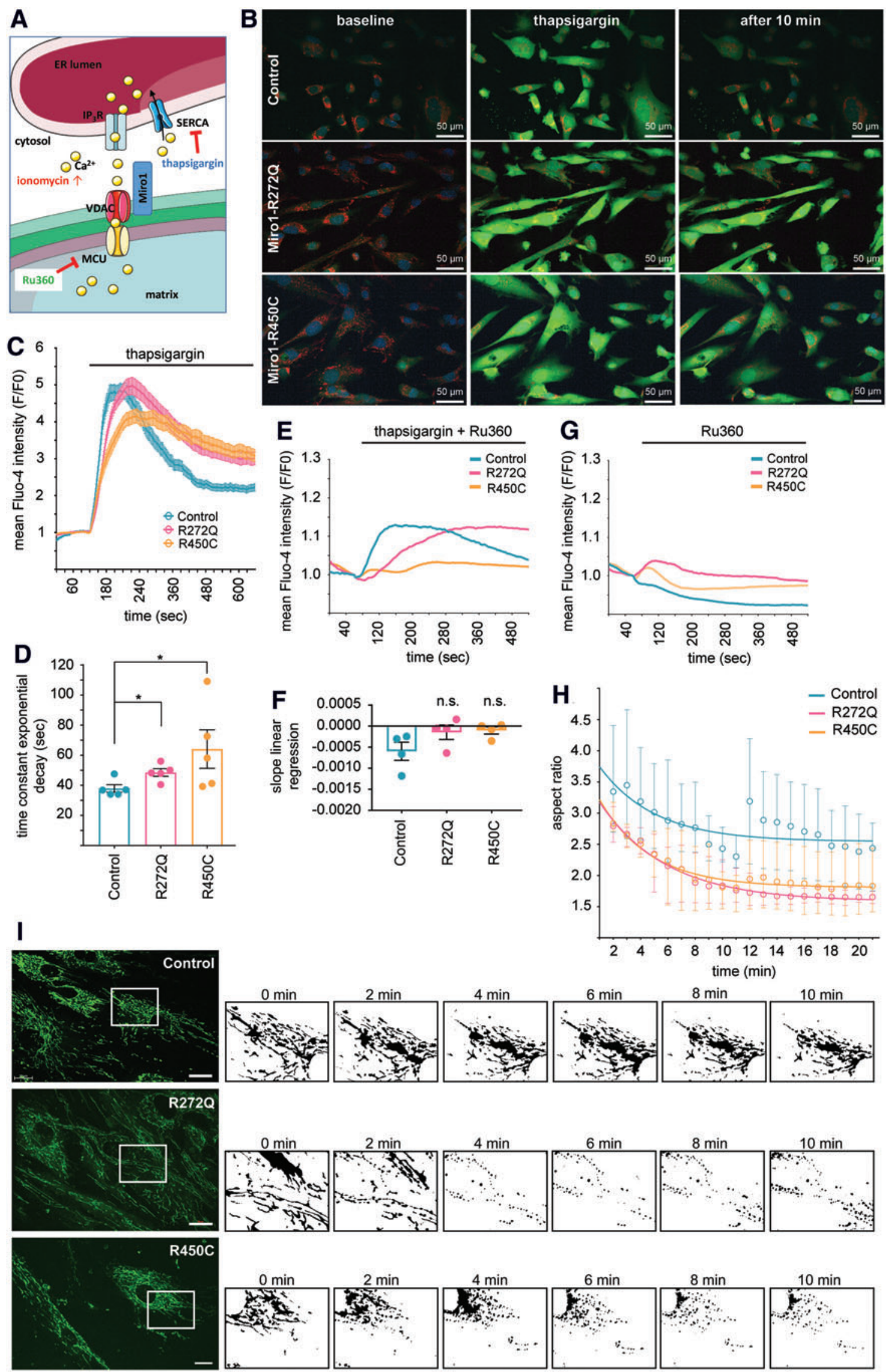
ionophore ionomycin to increase cytosolic calcium levels. Independent of their genotype, all cells reacted to the ionomycin exposure with mitochondrial fragmentation as reflected by a decrease in the aspect ratios. However, in both Miro1-mutant fibroblast lines, we observed an increased fragmentation of the mitochondrial network compared with control fibroblasts (Fig. 2H, I). These results suggest that the impaired calcium buffering capacity of Miro1-mutant cells results in prolonged and elevated cytosolic calcium levels, which subsequently cause an increased induction of calciummediated mitochondrial fragmentation.

\section{Decreased ER-mitochondrial contact sites in Miro1-mutant fibroblasts}

Closely related to its function in cellular calcium homeostasis, Miro1 is also involved in the regulation of ER-mitochondria contact sites (21). In light of the observed impaired mitochondrial calcium buffering in Miro1-mutant fibroblasts, we next studied the colocalization of the ER and mitochondria using MitoTracker Deep Red and ER-Tracker Green (Fig. 3A). We observed a significant reduction of ERmitochondria contacts in both patient-derived fibroblast lines compared with control lines, when normalized to cell count (Fig. 3B), ER area (Fig. 3C), or mitochondrial area (Fig. 3D).

Intriguingly, we also observed an overall reduction of ER area (Fig. 3E) and mitochondrial area (Fig. 3F) in Miro1-R272Q and R450C fibroblasts. These results were confirmed by immunocytochemistry of ER and mitochondrial marker proteins PDI and Tom20 (Fig. 3G). Subsequent colocalization analysis showed a significant reduction of ER-mitochondria contacts in Miro1-mutant fibroblasts (Fig. 3H), and ER area was likewise significantly reduced (Fig. 3I), whereas mitochondrial area showed a tendency to be reduced in Miro1-mutant fibroblasts compared with controls (Fig. 3J).

Our results point to a reduction of ER-mitochondria contact sites in fibroblasts with mutations in Miro1.

\section{Mutant Miro1 protein leads to reduction of mitochondrial mass}

Based on the reduced mitochondrial area observed during our microscopy analysis of ER-mitochondria contact sites (Fig. 3F), we further investigated mitochondrial mass in Miro1-mutant fibroblasts. To this end, we performed Western blotting analyses of different mitochondrial marker proteins. First, we confirmed a reduction of Tom 20 in the mutant fibroblasts (Fig. 4A, B). In addition, we quantified the abundance of the mitochondrial matrix marker Hsp60 $(8,35)$. Indeed, Hsp60 protein levels were found to be significantly reduced in mutant compared with control fibroblasts (Fig. 4C, D). Finally, we investigated the protein levels of Miro1 itself and also confirmed a reduction in fibroblasts expressing mutant Miro1 (Fig. 4E, F).

As both the Miro1-R272Q and the Miro1-R450C mutant fibroblast lines were heterozygous, these results raised the question whether the observed mitochondrial phenotypes are due to a gain-of-function effect or due to the loss of Miro1 function. To answer this question, we generated an M17 cell model with stable knockdown of endogenous RHOT1 and transient overexpression of the PD-associated Miro1 variants (Supplementary Fig. S1). Western blot analyses revealed that knockdown of RHOT1 alone (untransfected M17 cells+microRNA [miRNA]) had no effect on protein levels of Tom20 or the mitochondrial matrix marker $\operatorname{MnSOD}(8,35)$, whereas overexpression of Miro1-R272Q or Miro1-R450C, but not wild type (WT)-Miro1, led to a significant reduction of Tom20 (Fig. 4G, H) and MnSOD (Fig. 4I, J), respectively. From these results, we concluded that the R272Q and R450C mutations in Miro1 cause a toxic gain of function.

\section{Mitochondrial turnover is increased in Miro1-mutant fibroblasts}

Previous studies reported that the PINK1/Parkin-driven proteasomal degradation of Mirol is part of the initial step of mitophagy $(4,28,38,49,50)$. Given the observed reduced levels of Miro1 protein and mitochondrial mass in Miro1mutant cells (Fig. 4), we were interested to investigate the underlying degradation pathways. Patient-derived fibroblasts were therefore treated with the proteasomal inhibitor MG132 and bafilomycin $\mathrm{A}_{1}$, an inhibitor of the lysosomal degradation pathway. Western blot analysis showed an increase of Miro1 protein levels (Fig. 5A, B) as well as Tom20 protein levels (Fig. 5C, D) after MG132 treatment, but not after bafilomyci$\mathrm{nA}_{1}$ treatment, suggesting that both Miro1 and Tom20 are predominantly degraded by the proteasome. This result is in line with the literature, indicating that Miro1 and Tom20 are targeted by PINK1/Parkin for proteasomal degradation during mitophagy $(4,8,28,35,38,52)$. To further test this hypothesis,

FIG. 3. Decreased ER-mitochondrial contact sites in Miro1-mutant fibroblasts. (A) Native fibroblasts were stained with MitoTracker Deep Red (magenta) and ER-Tracker Green. Images were obtained with a $40 \times$ objective $(n=3)$. Scale bars indicate $50 \mu \mathrm{m}$. Colocalization of ER and mitochondria was analyzed in the merged-channel images. The white squares in the merged images indicate the zoomed regions shown for the colocalization panel; colocalization events are highlighted as white dots (see colocalization panel). (B) Colocalization events of mitochondria and ER pixel from (F) were normalized to cell number, (C) to ER area, or (D) to mitochondrial area. (E) ER area (pixel) per cell was analyzed from live cell microscopy data of ER-Tracker. (F) Mitochondrial area (pixel) per cell was analyzed from live cell microscopy data of MitoTracker Deep Red. (G) Native fibroblasts were fixed and labeled with antibodies against Tom20 (magenta) and PDI (green) for subsequent immunofluorescent microscopy analysis of mitochondria and ER colocalization. Colocalization of ER and mitochondria was analyzed in the merged-channel images. The white squares indicate the zoomed regions shown in the colocalization panel. Colocalization events are highlighted as white dots. Images were obtained with a $40 \times$ objective. (H) Colocalization events of mitochondria and ER pixel from $(\mathbf{G})$ were normalized per cell ( $n=3$, with approximately 8090 cells per cell line per experiment). (I) ER area (pixel) per cell was analyzed by quantification of the PDI staining. (J) Mitochondrial area (pixel) per cell was analyzed by quantification of the Tom 20 staining. Significance was calculated by the Kruskal-Wallis test $(n=3)$. All data indicated as mean \pm SEM. $* * p<0.01$; *** $p \leq 0.001$; **** $p<0.0001$. Color images are available online. 

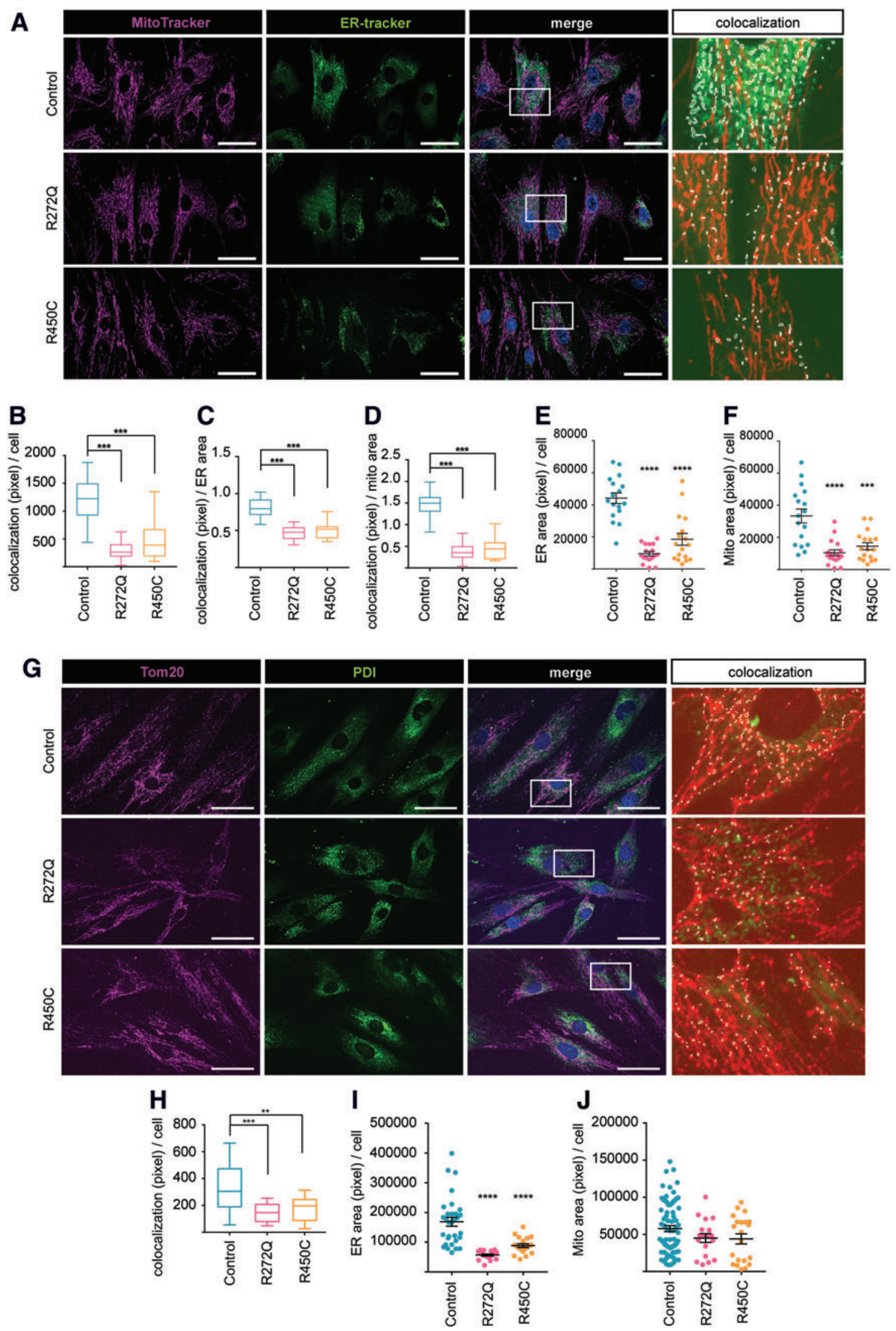
A

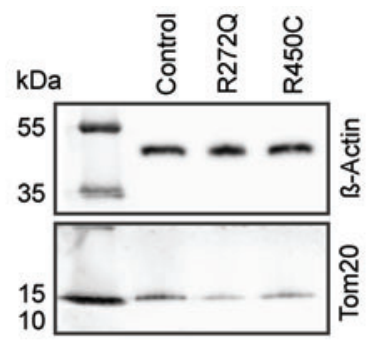

B

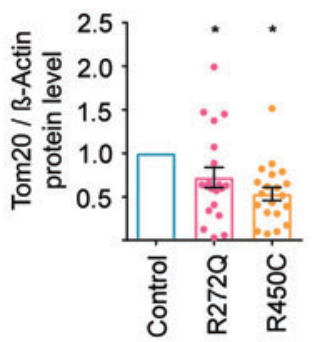

C

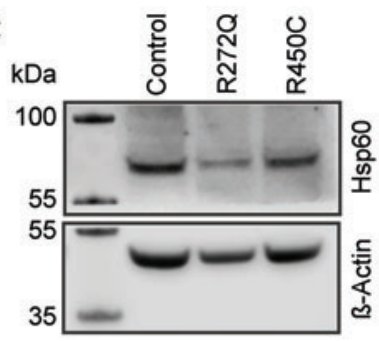

D

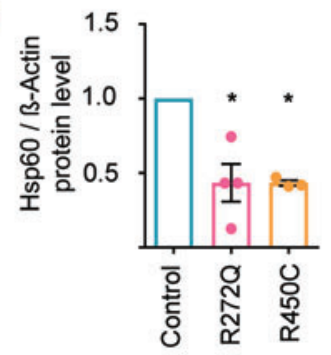

E

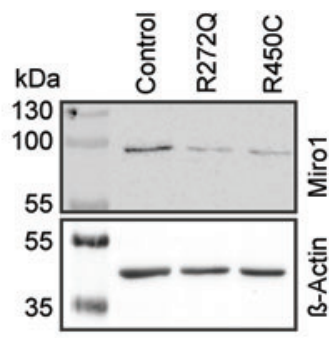

F

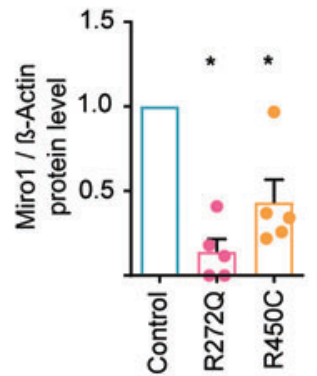

G
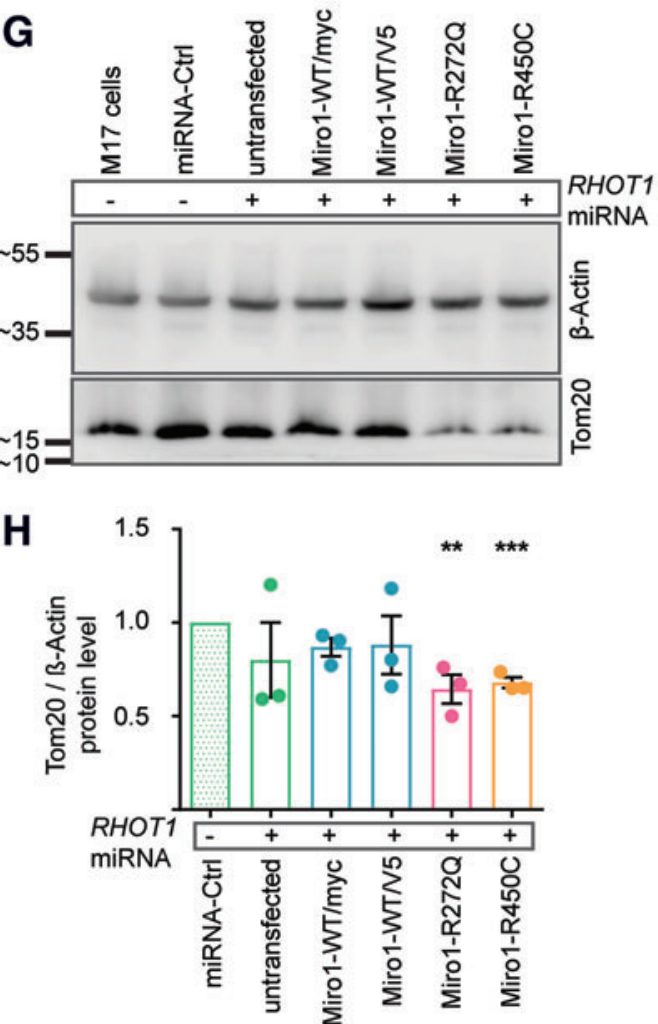
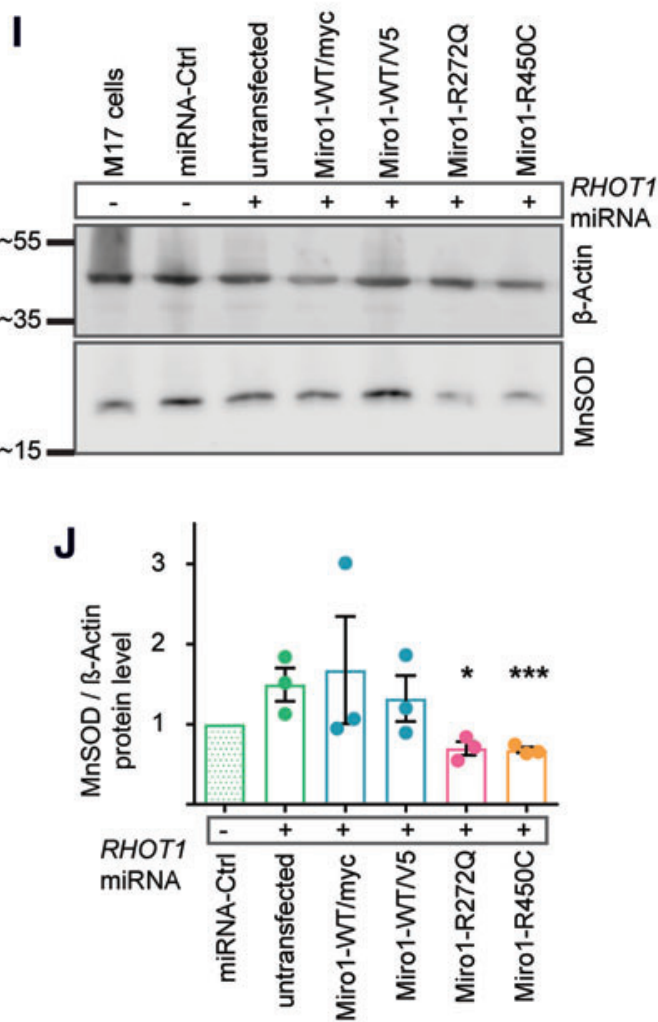

FIG. 4. Mutant Miro1 protein leads to reduction of mitochondrial mass. (A) Representative Western blot of Tom20 in immortalized fibroblasts. (B) Quantification of Tom20 protein level in immortalized fibroblasts from (A). Significance tested with the Wilcoxon test $(n=20)$. (C) Representative Western blot image of Hsp60 protein in immortalized fibroblasts. (D) Quantification of Hsp60 normalized to $\beta$-actin from (C). Significance assessed using the Mann-Whitney test ( $n=4)$. (E) Representative Western blot image of Miro1 protein in immortalized fibroblasts. (F) Quantification of Western blot analysis of Miro1 protein levels from (E). Significance determined using the Wilcoxon test $(n=5)$. (G) Representative Western blot image of Tom20 and (I) MnSOD proteins in M17 cells with stable knockdown of endogenous RHOT1 and transiently overexpression of Miro1 variants. (-) Indicates M17 cells without knockdown of endogenous RHOT1. (+) Indicates knockdown of endogenous RHOT1 by stable transfection with the RHOT1-targeting miRNA-2471 (RHOT1 miRNA). M17 cells were transfected with Miro1-WT/myc (in pRK5-myc vector), Miro1-WT/V5, Miro1-R272Q, or Miro1-R450C (in pcDNA3.1/V5-HisA vector). (H) Quantification of Tom20 protein levels from $(\mathbf{G})(n=3)$. (J) Quantification of MnSOD protein levels from $(\mathbf{I})(n=3)$. All data indicated as mean \pm SEM. $* p \leq 0.05$; $* * p \leq 0.01 ; * * * p \leq 0.001$. miRNA, microRNA. Color images are available online. 
A

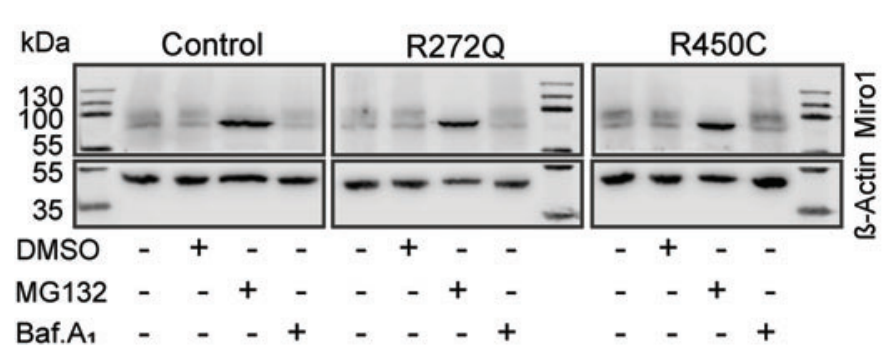

C

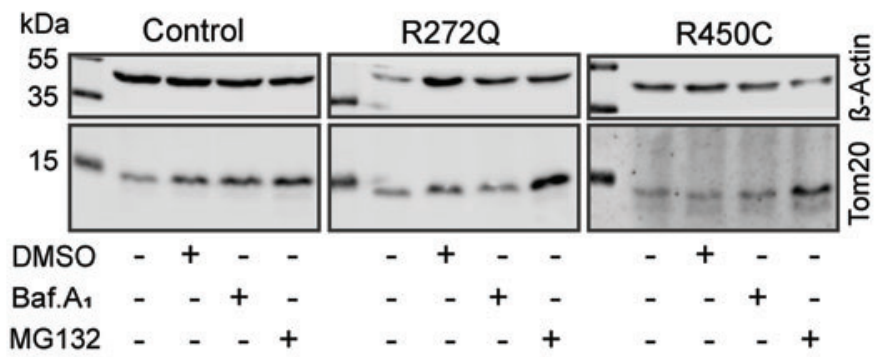

B

Control

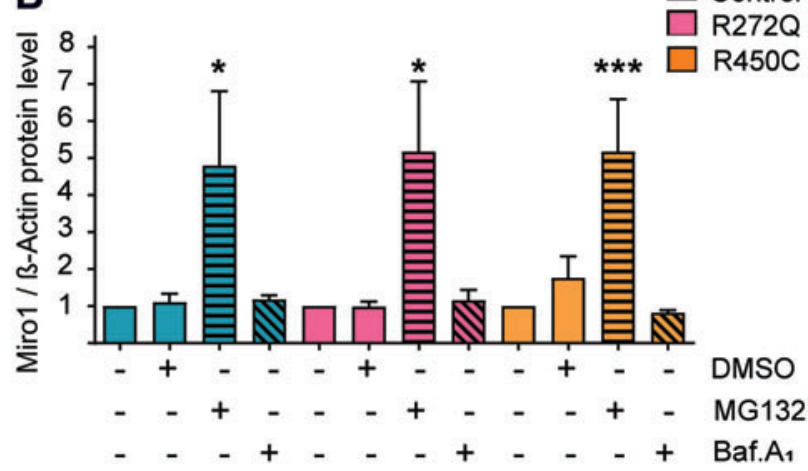

D

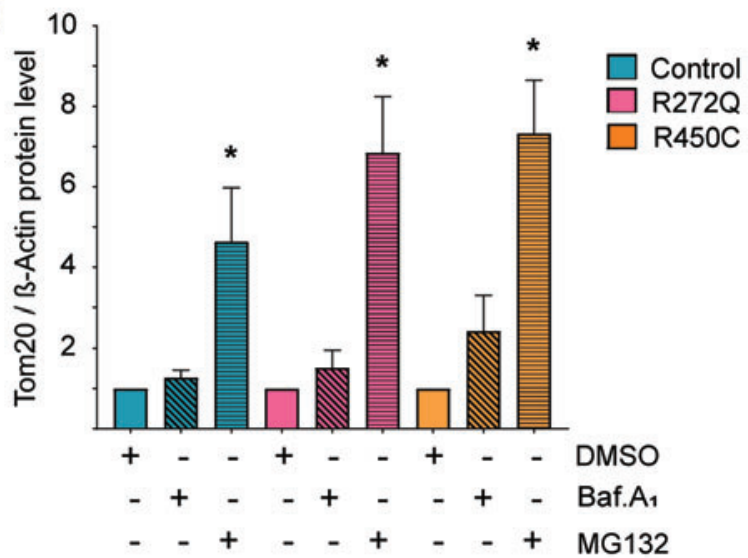

E

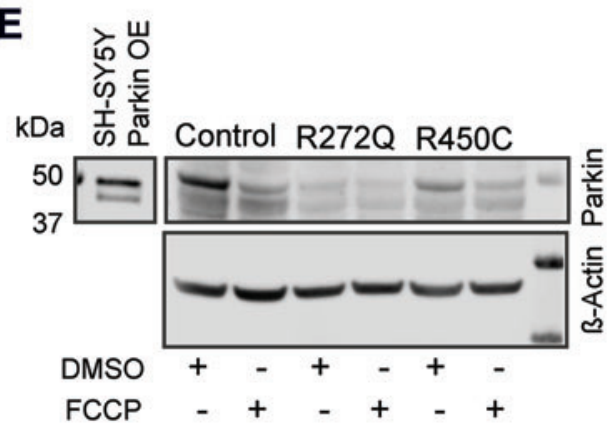

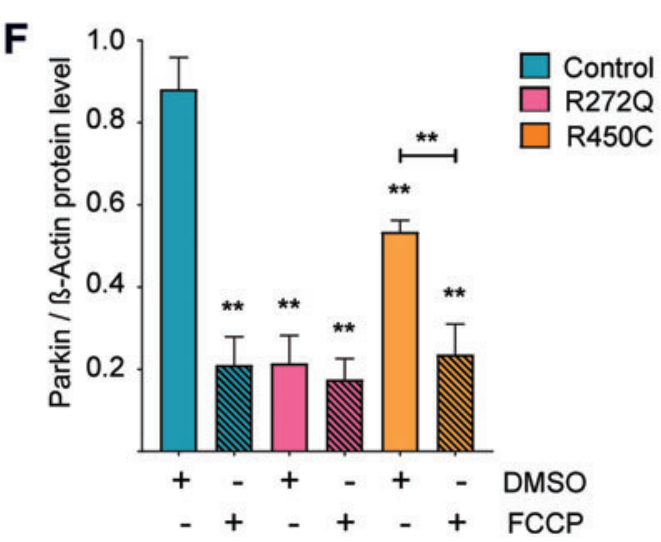

FIG. 5. Mitochondrial turnover is increased in Miro1-mutant fibroblasts. (A) Representative Western blot image of Miro1 in immortalized fibroblasts treated with $10 \mu M$ MG132 for $24 \mathrm{~h}$ or with $10 \mathrm{n} M$ bafilomycin $\mathrm{A}_{1}$ for $48 \mathrm{~h}$. (B) Quantification of Mirol protein level from Western blots displayed in (A). Significance assessed with the Wilcoxon test $(n=3-7)$. (C) Western blot image for Tom 20 protein in immortalized fibroblasts treated with $10 \mathrm{n} M$ bafilomycin $\mathrm{A}_{1}$ for $48 \mathrm{~h}$ or with $10 \mu M$ MG132 for $24 \mathrm{~h}$, respectively. (D) Quantification of Tom20 protein levels from Western blot analysis shown in (C). Significance assessed using the Wilcoxon test $(n=5)$. (E) Representative Western blot image of Parkin protein. Left panel shows Parkin bands in SH-SY5Y cells overexpressing Parkin. Right panel shows endogenous Parkin in immortalized fibroblasts treated with $10 \mu M$ FCCP for $14 \mathrm{~h}$. (F) Quantification of Parkin protein levels normalized to $\beta$-actin from (E). Significance calculated by the Mann-Whitney test $(n=5)$. All data indicated as mean \pm SEM. ${ }^{*} p \leq 0.05 ; * * p \leq 0.01$; $*_{* *} p \leq 0.001$. FCCP, carbonyl cyanide-4-(trifluoromethoxy)phenylhydrazone. Color images are available online.

we assessed Parkin levels in patient-derived fibroblasts. Carbonyl cyanide-4-(trifluoromethoxy)phenylhydrazone treatment for $14 \mathrm{~h}$ significantly decreased Parkin levels in control fibroblasts, suggesting an activation of mitophagy (Fig. 5E, F). By contrast, Parkin levels were already found to be signifi- cantly reduced at baseline conditions in both Miro1-mutant fibroblast lines (Fig. 5F). These results, together with the reduction of mitochondrial mass (Fig. 4), support that mitochondria undergo increased clearance in Miro1-mutant fibroblasts under basal conditions. 
LC3-dependent autophagy is affected in Miro1-mutant fibroblasts

Since we observed reduced mitochondrial mass (Fig. 4) and activation of mitochondrial clearance (Fig. 5), we next analyzed autophagy in immortalized Miro1-mutant and control fibroblasts. To assess autophagic flux, we treated cells with bafilomycin $A_{1}$. Western blot analysis revealed that LC3-II protein levels normalized to $\beta$-actin (19), as well as the ratio of LC3-II to LC3-I protein levels increased significantly in control fibroblasts, but not in the Miro1-mutant fibroblast lines (Fig. 6A, B), indicating a reduced capacity to enhance the autophagic flux.

To further characterize the autophagy pathway and based on our findings of reduced ER-mitochondrial contact sites in cells expressing mutant Miro1, we stained fibroblasts with fluorescently labeled phosphatidylserine (PS) (18:1 NBDPS). PS is transferred at ER-mitochondria contact sites from the ER to mitochondria, where it is converted to phosphatidylethanolamine (PE). $\mathrm{PE}$ is then transferred through the ER-mitochondria contact sites back to the ER and contributes together with the cytosolic LC3-I to create autophagosomes (Fig. 7F). In this assay, the formation of autophagosomes is reflected by translocation of the 18:1 NBD-PS fluorescence signal from mitochondria to the cytosol $(14,31)$ (Fig. 6C). Fetal bovine serum (FBS) starvation for $2 \mathrm{~h}$ induced autophagosome formation in control fibroblasts, whereas Miro1-mutant fibroblasts showed no increased autophagosome formation compared with the untreated condition (Fig. 6D). To specifically analyze mitophagy, fibroblasts were transfected with mito-DsRed and eGFP-LC3 and subsequently treated with carbonyl cyanide 3-chlorophenylhydrazone (CCCP) to induce mitophagy or with bafilomycin $\mathrm{A}_{1}$ to inhibit autophagy. Mitophagy was subsequently assessed by quantification of mitochondria colocalizing with LC3 puncta, which allowed us to analyze only those autophagosomes that are involved in mitochondrial degradation (Fig. 6E, F) (19). Under CCCP or bafilomycin $\mathrm{A}_{1}$ treatment, the colocalization of mito-DsRed-labeled mitochondria and eGFP-LC3 puncta significantly increased in control fibroblasts, whereas no significant increase could be observed in Miro1-mutant fibroblasts, compared with baseline conditions (Fig. 6E). Our results support the idea of already elevated mitophagy rates in the $\mathrm{R} 272 \mathrm{Q}$ and $\mathrm{R} 450 \mathrm{C}$ fibroblasts at baseline, as indicated by a higher frequency of mitochondria-LC3 colocalizing events in the untreated mutant cells compared with untreated control cells (Fig. 6E). These results suggest that, while the total autophagosome formation under baseline conditions is not affected in Miro1muant cells compared with controls, the capacity to further upregulate autophagosome formation is inhibited in those cells (Fig. 6D). Furthermore, the created autophagosomes are involved in increase mitochondrial turnover, which likewise lacks the capacity for further upregulation under stress conditions (Fig. 6E).

\section{Mutations in Miro1 lead to increased LC3-independent autophagy and impaired energy metabolism}

Our results suggest alterations of LC3-dependent autophagy in Miro1-mutant fibroblasts (Fig. 6), significantly reduced mitochondrial mass (Figs. 3 and 4) and increased mitochondrial clearance (Fig. 5). Therefore, we also investigated an alternative LC3-independent clearance pathway, where autophagosomes are derived from the Golgi apparatus and their formation is mediated by Rab9 (33). When analyzing protein levels of Rab9 in cytosolic and mitochondrial fractions by Western blotting, we found that Rab9 levels were significantly reduced in mitochondrial fractions of Miro1-mutant fibroblasts compared with control fibroblasts (Fig. 7A, B). To test whether these results were linked to autophagy, we treated fibroblasts with bafilomycin $A_{1}$. This experiment showed an increase in Rab9 levels after bafilomycin $A_{1}$ treatment in Miro1mutant fibroblasts, but not in control cells (Fig. 7C, D), suggesting a higher lysosomal turnover of Rab9. From these results, we concluded that mitochondrial degradation in Miro1-mutant fibroblasts is additionally driven by the Atg5/LC3-indipendent macroautophagy pathway.

Finally, since mitophagy and calcium homeostasis are closely linked to mitochondrial energy metabolism, we next sought to investigate the ATP production in our patient and control cultures. Measuring cellular ATP concentrations under baseline conditions showed significantly reduced

FIG. 6. LC3-dependent autophagy is affected in Miro1-mutant fibroblasts. (A) Representative Western blot image of immortalized fibroblasts treated with $10 \mathrm{n} M$ bafilomycin $\mathrm{A}_{1}$ for 3, 6, or $24 \mathrm{~h}$. (B) Densitometry analysis of Western blot for LC3-II normalized to $\beta$-actin (upper graph) and the ratio of LC3-II/LC3-I protein levels (lower graph) from (A). Significance calculated by the Friedman test $(n=3)$. (C) Immortalized fibroblasts were transfected with mito-DsRed and labeled with 18:1 NBD-PS. Then, cells were starved in medium without FBS for $2 \mathrm{~h}$ for subsequent live cell imaging, using a $63 \times$ objective. Cell selection shows microscopy images with mito-DsRed-labeled mitochondria (red) and 18:1 NBD-PS (green). Cells were manually selected (dashed pink outline) to ensure that only 18:1 NBD-PS-labeled autophagosomes in the cytosol were analyzed. The colocalization panel shows the selected cells from the data analysis. White squares indicate the regions, which were shown in the zoom panel. Autophagosomes were identified as green particles, which are not colocalizing with the mito-DsRed signal (white arrows). (D) Quantification of autophagosome formation from images shown in $(\mathbf{C})$. Significance calculated by the Wilcoxon test $(n=3)$. (E) Colocalization of mitochondria and LC3 pixel from (F) were quantified and normalized to cell number. Significance assessed using the Mann-Whitney test $(n=3$, with $\sim 30$ cells per cell line). (F) Immortalized fibroblasts were transfected with mito-DsRed and eGFP-LC3. Twenty-four hours after transfection, cells were treated with $25 \mu M \mathrm{CCCP}$ or with $10 \mathrm{n} M$ bafilomycin $\mathrm{A}_{1}$ for 2 or $6 \mathrm{~h}$, respectively. The left panels show the microscopy images obtained with a $40 \times$ objective. The right panels show the colocalization analysis. The outlines of analyzed mitochondria are indicated in green, whereas the outlines of analyzed LC3 puncta are indicated in red. The colocalization regions of both organelles are indicated in yellow. Scale bars indicate $20 \mu \mathrm{m}$. All data indicated as mean \pm SEM. ${ }^{*} p \leq 0.05 ; * * p \leq 0.01 ; * * * p \leq 0.001 ; * * * * p<0.0001$. FBS, fetal bovine serum; PS, phosphatidylserine. Color images are available online. 


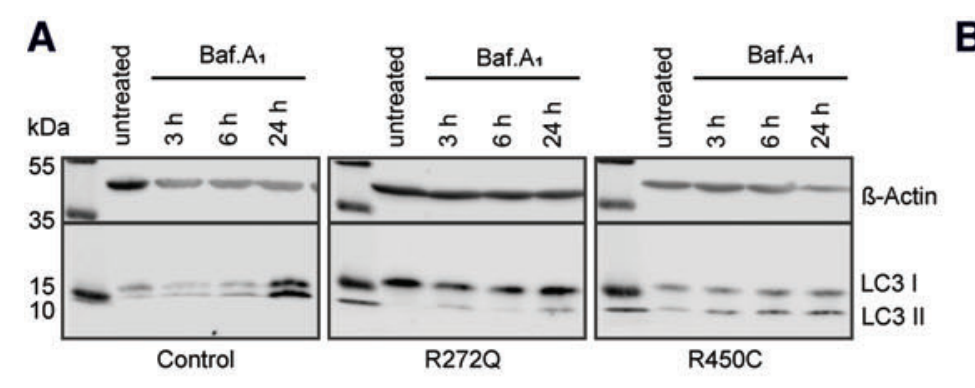

C
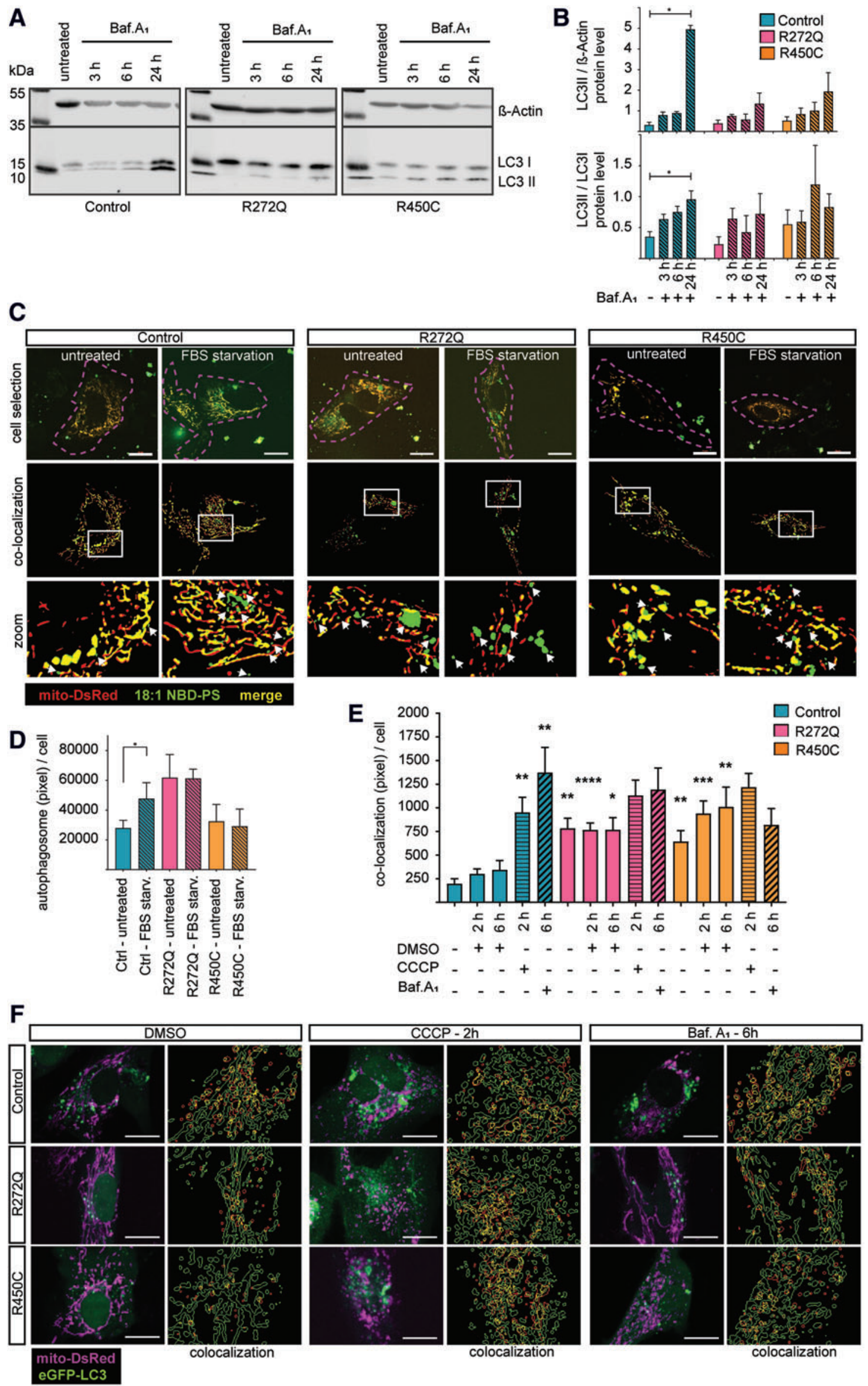

colocalization

colocalization 

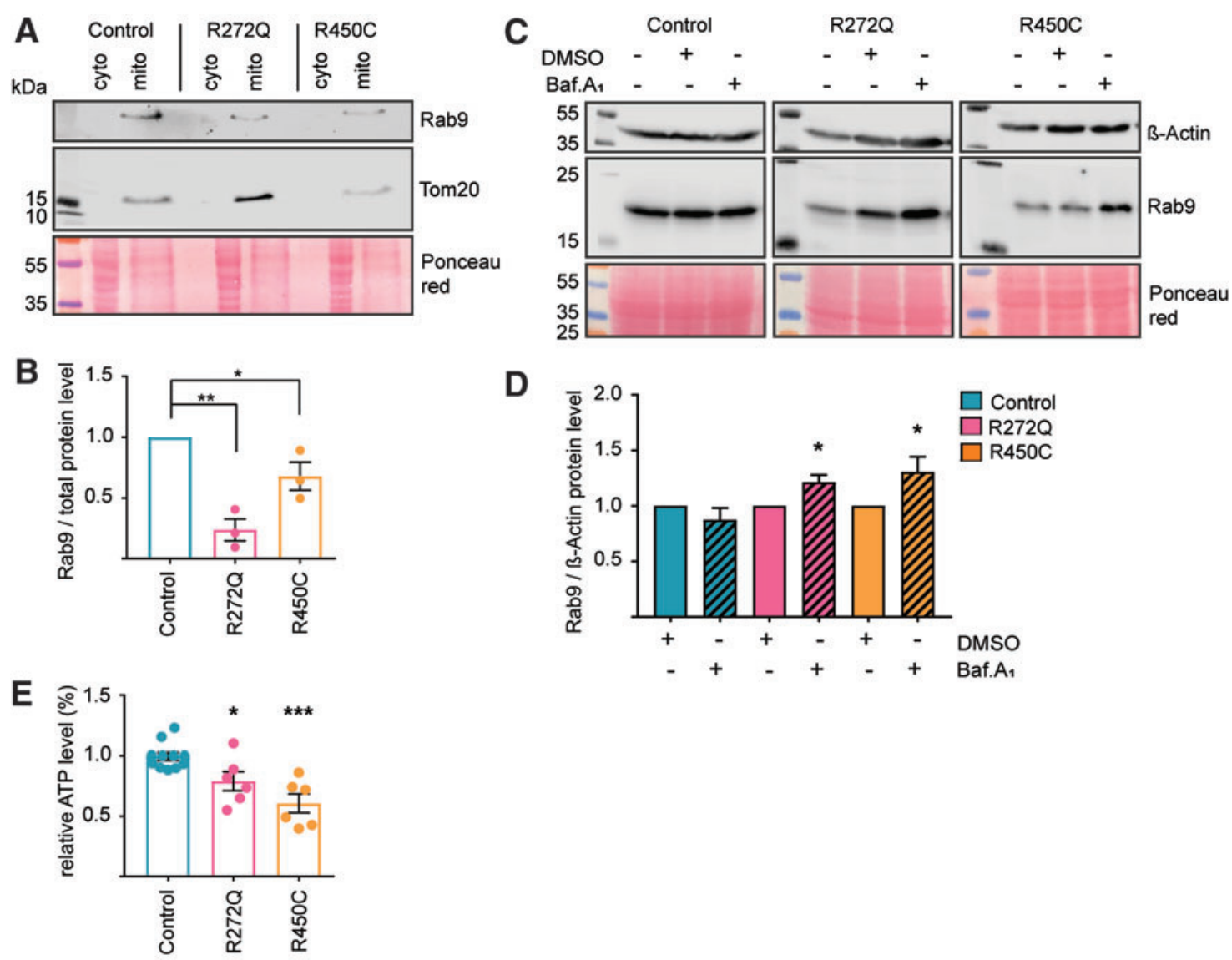

$\mathbf{F}$
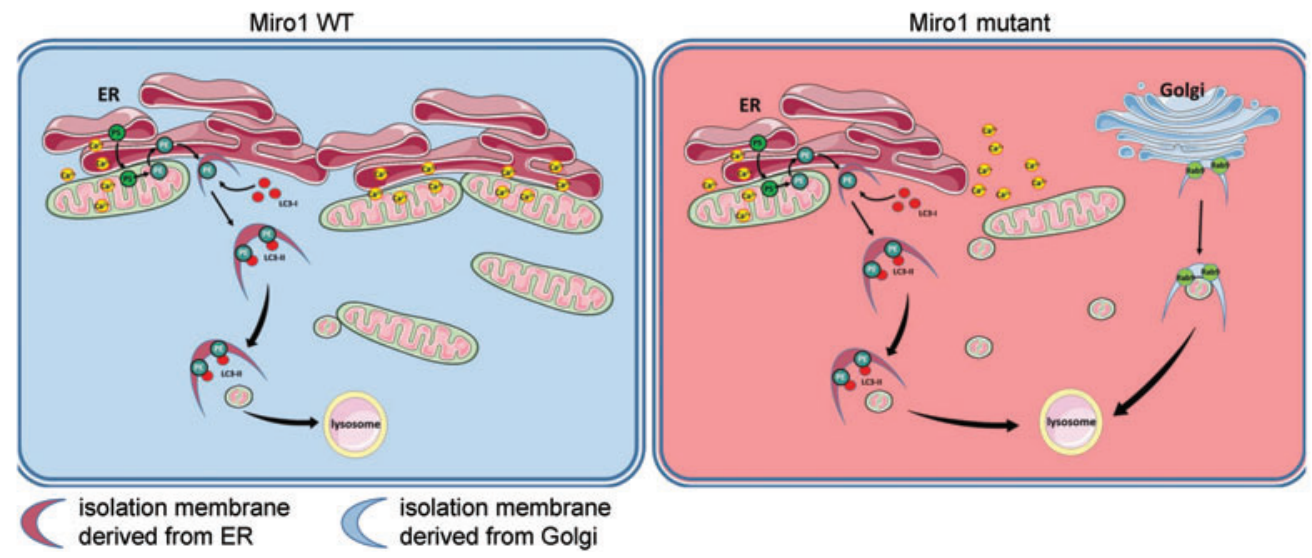

FIG. 7. Mutations in Miro1 lead to increased LC3-independent autophagy and impaired energy metabolism. (A) Crude mitochondrial fractions were obtained from immortalized fibroblasts. Rab9 levels were analyzed by Western blot. (B) Quantification of Rab9 protein levels in mitochondrial fractions from (A) $(n=3)$. (C) Representative Western blot image of Rab9 in whole cell lysates of immortalized fibroblasts treated with $10 \mathrm{n} M$ bafilomycin $\mathrm{A}_{1}$ for $4 \mathrm{~h}$. (D) Quantification of Rab9 protein levels from (C). Significance determined using the Wilcoxon test $(n=6-11)$. (E) Measurement of steady-state ATP level under baseline conditions in immortalized fibroblasts. Significance assessed with the Mann-Whitney test $(n=6)$. (F) Schematic overview of the mechanism of impaired ER-mitochondria contact sites and increased mitophagy in Miro1 mutant background. $* p<0.05 ; * * p<0.01 ; * * *<<0.001$. Color images are available online.

steady-state levels in both mutant fibroblast lines compared with control cells (Fig. 7E).

\section{Discussion}

Increasing evidence supports a contribution of impaired energy metabolism and mitochondrial dynamics to the path- ogenesis of monogenic and sporadic PD, that is, for at least seven established PD genes (PINK1, Parkin, DJ-1, LRRK2, ATP13A2, SNCA, and VPS35), a role in mitochondrial homeostasis and clearance has been described (24). Within this context, the encoded proteins interact with other targets, which are potentially relevant to the pathogenesis of PD. One of these targets is Miro1, which has been shown to 
directly interact with PINK1 and Parkin (4). Moreover, recent studies suggest a function of Miro1 together with LRRK2 in the regulation of damage-induced mitochondrial arrest (16). The pathological relevance of Miro1 was supported by the lethality of newborn homozygous RHOT1-knockout mice (32) and larvae of dMiro-knockout flies (13).

Here, we describe for the first time phenotypes in fibroblasts derived from PD patients carrying mutations in RHOTI. These mutations lead to a decrease in ER-mitochondria contact sites, which consequently caused (i) impaired cellular calcium homeostasis and (ii) increased calcium-induced mitochondrial fragmentation. These phenotypes ultimately (iii) induce mitochondrial clearance. However, the LC3-dependent formation of autophagosomes lacks the capacity to further promote mitophagy under stress conditions. Mitophagy is therefore additionally driven by LC3-independent autophagy via Rab9, resulting in (iv) reduced mitochondrial mass in Miro1-mutant cells (see overview Fig. 7F).

The herein described Miro1-muant fibroblast lines displayed strikingly similar phenotypes, although the R272Q and R450C mutations are located in different domains of the protein, that is, the EF-hand and the C-terminal GTPase domain. Both domains have been shown to form a unique side-by-side three-dimensional structure that facilitates their close interplay (20), which is crucial for the calcium-sensing ability of Miro1 (9, 20, 21, 37, 42). In light of these previous reports, we conclude from our data that both mutations in Miro1 disrupt the proteins calcium-sensing function.

The importance of cellular calcium regulation at ER-mitochondrial contact sites for the function and survival of neuronal cells was recently highlighted by studies in drosophila. Lee et al. identified Mirol as regulator of calcium transporters at the ER-mitochondrial contact sites, a function that was independent of Miro1's role in mitochondrial transport. Inactive Miro1 was found to cause mitochondrial calcium depletion and metabolic dysfunction, leading to impaired neuronal stem cell development in flies (26).

ER-mitochondrial contact sites not only regulate cytosolic and mitochondrial calcium homeostasis but also autophagy. Within this mechanism, Mirol acts as receptor at the outer mitochondrial membrane to sense cytosolic calcium levels. Upon increase of calcium levels, Miro1 mediates Drp1/Fis1independent mitochondrial fragmentation, also called MiST, and subsequent mitophagy. Disruption of the calcium binding ability of Miro1 leads to impaired regulation of calcium homeostasis and mitophagy (31). Indeed, this is in line with our findings of impaired cellular calcium homeostasis and increased calcium-induced mitochondrial fragmentation in Miro1-mutant fibroblasts.

Calcium dyshomeostasis is commonly observed in neurological diseases, and recently, the regulation of calcium homeostasis and autophagy at ER-mitochondrial contact sites came into focus in the context of PD. Drosophila expressing a PINK1 LoF mutation or the PD-associated mutation G2019S in LRRK2 displayed impaired calcium homeostasis at ER-mitochondrial contact sites, which resulted in mitochondrial dysfunction and loss of dopaminergic neurons, and Mirol was identified as key player in this process (25). Also, Parkin was found to be involved in the regulation of ER-mitochondria contact sites. Mirroring the phenotypes found in Miro1-mutant fibroblasts in this study, Calì et al. showed that knockdown of Parkin in SH-SY5Y cells results in mitochondrial fragmentation, alterations of mitochondrial calcium transients, and a reduction of ER-mitochondria contact sites. They concluded that, just like Miro1, Parkin is involved in the maintenance of the mitochondrial network integrity via the regulation of the ER-mitochondria contact sites and calcium transfer between both organelles (7).

Similar observations were made in S2R+drosophila cells or mouse embryonic fibroblasts with knockdown of Parkin and fibroblasts derived from a PD patient with compound heterozygous mutant Parkin (R275W, exon 3 deletion) (3). The results of this study suggested that Parkin regulates the function of ERmitochondrial contact sites by ubiquitination of Mfn2 (3). Also, LoF models of Parkin and PINK1 in fly ventral neurons and human induced pluripotent stem cell-derived hypothalamic neurons resulted in alterations of ER-mitochondrial connections and a thereof resulting deregulation of PS transfer, in turn leading to impaired production of neuropeptide-containing vesicles. The resulting changes of neuropeptidergic neurotransmission caused impaired sleep patterns in the PD fly model (45).

It is worth noting that some studies found an increase of ER-mitochondria contact sites, where others found a decrease, caused by impaired PINK1, Parkin, or Miro1 function. These differences seem to be cell type-specific, as knockdown of Parkin in nonneuronal mitotic cells leads to a reduction of ER-mitochondrial connections $(3,7)$, but knockdown of PINK1, Parkin, or Miro1 in neurons was associated with increased contact sites $(25,45)$.

In conclusion, our results support an important role of Miro1 in cellular calcium homeostasis and autophagy, highlighting RHOTI as candidate gene in the pathogenesis of neurodegenerative disorders such as PD.

\section{Materials and Methods}

\section{Screening for PD patients with mutations in RHOT1}

DNA was obtained from 752 German PD patients (average age of onset of $59.4 \pm 13.2$ years, average age of sample collection of $65.7 \pm 10.2$ years) and 282 age-matched healthy control individuals (average age $72 \pm 4.4$ years) from the MEMO study (5). Informed consent was obtained from patients and approved by the ethics committee of the Medical faculty and the University Hospital Tübingen, Germany. Ninety-two samples of healthy individuals from the TREND study (15) served as additional control cohort. Polymerase chain reaction amplification of exons 2-21 of RHOT1 (Ensembl.org: RHOT1-002, ENST00000358365) from wholeblood DNA samples was performed using the primers listed in Supplementary Table S1 (Metabion, Germany). SYBR Green on the LightCycler 480 High Resolution Master (Roche) and subsequent high-resolution melting analysis were used for mutation screening. Potential mutation sites were validated by Sanger sequencing.

Genotyping of additional cohorts for the herein described RHOTl variants was performed by the central genotyping core at the Institute of Human Genetics, Helmholtz Zentrum München, Neuherberg, Germany, using a matrix-assisted laser desorption/ionization time-of-flight mass spectrometry on a MassARRAY System (Agena Bioscience, San Diego, CA). We included 662 age-matched control individuals from the KORA cohort (KORA, Cooperative Research in the Region of Augsburg, Germany) and 1238 PD patients of German origin (51). The genotyping core was blinded to case-control status. Cleaned extension products were analyzed by a mass 
spectrometer (Bruker Daltonik) and peaks identified using the MassARRAY Typer 4.0.2.5 software (Agena Bioscience). The average call rate of the variants was $97 \%$.

In silico prediction of pathogenic effects of RHOT1 mutations

ANNOVAR (47) was used to annotate the RHOT1 mutations using the dbNSFP database version 3.0 (29). The following prediction tools were used: SIFT (23), PolyPhen2 (1), Mutation Taster (39), Mutation assessor (36), FATHMM (40), LRT (likelihood ratio test) (10), radial SVM, and LR pred (11).

\section{Three-dimensional modeling of human Miro1}

A homology model for human Miro1 was derived from the crystal structure of the drosophila ortholog (PDB: 4COJ) using the I-TASSER software with default parameters (53). To visualize the mutations in the homology model, the WT residues were replaced by the rotamers with the highest probability using the "Rotamers" tool in the software Chimera (41), and an energy minimization was applied to these residues with standard settings.

\section{Genetic burden analysis for RHOT1}

We used the gnomAD browser to analyze the mutational burden for RHOT1 (27). Z-scores for missense and synonymous variants were calculated from numbers of observed over expected variants and positive $\mathrm{z}$-scores indicate that there are fewer variants than statistically expected. The o/e score and the pLI score indicate the tolerance of a gene against LoF variants. Low o/e values indicate that the gene is under stronger selection. The closer to 1 , the less tolerant the gene is against LoF variants and genes with pLI $\geq 0.9$ are considered to be extremely intolerant to $\mathrm{LoF}$ variants (27).

\section{Immortalization and culture of fibroblasts}

Skin biopsies were obtained from two female PD patients at the age of 78 years (Miro1-R272Q) or 54 years (Miro1$\mathrm{R} 450 \mathrm{C}$ ). Control fibroblasts were gender- and age-matched to patient-derived fibroblasts and obtained from the NeuroBiobank of the University of Tübingen, Germany. Informed written consent of all individuals was obtained at the University Hospital Tübingen, Germany. Fibroblasts were immortalized with a pLenti-III-SV40 construct (Cat. No. G203; Applied Biological Materials, Inc., Richmond, Canada). All fibroblasts were grown in Dulbecco's modified Eagle's medium (DMEM)+/+ (containing 4.5 g/L D-glucose, $15 \%$ FBS, 1\% Pen/Strep; Thermo Fisher Scientific, Braunschweig, Germany). Cells were tested for Mycoplasma contamination on a monthly base using the Plasmo Test ${ }^{\mathrm{TM}}$ Detection Kit (InvivoGen).

\section{Generation of $\mathrm{M} 17$ model with knockdown} of endogenous RHOT1 and overexpression of Miro1

The human neuroblastoma cell line M17 was grown in DMEM/F12+/+ medium (DMEM/Ham's-F12 + 15\% FBS +1\% L-glutamine $+1 \%$ nonessential amino acids $+1 \%$ Pen/Strep). Cells were split using Trypsin-EDTA $(0.05 \%)$ and phenol red
(Thermo Fisher Scientific). We introduced a stable knockdown of endogenous RHOT1 employing the BLOCK-iT Inducible Pol II miR RNAi Expression Vector Kit (Invitrogen $\mathrm{GmbH}$, Karlsruhe, Germany) according to the manufacturer's protocol. We designed the following single-stranded nucleotide oligomers, targeting different regions of $\mathrm{RHOTI}$ : miRNA-524 (top strand: 5' TGC TGT TTA TGA GAG GAA TCC ATC GAG TTT TGG CCA CTG ACT GAC TCG ATG GAC CTC TCA TAA A 3'; bottom strand: 5' CCT GTT TAT GAG AGG TCC ATC GAG TCA GTC AGT GGC CAA AAC TCG ATG GAT TCC TCT CAT AAA C 3'); miRNA1335 (top strand: 5' TGC TGT AAA TAA GTC GTG AGC GTC CAG TTT TGG CCA CTG ACT GAC TGG ACG CTC GAC TTA TTT A 3'; bottom strand: 5' CCT GTA AAT AAG TCG AGC GTC CAG TCA GTC AGT GGC CAA AAC TGG ACG CTC ACG ACT TAT TTA C 3'); or miRNA-2471 (top strand: 5' TGC TGT ATG CTA GCC AAT ACT GCA GTG TTT TGG CCA CTG ACT GAC ACT GCA GTT GGC TAG CAT A 3'; bottom strand: 5' CCT GTA TGC TAG CCA ACT GCA GTG TCA GTC AGT GGC CAA AAC ACT GCA GTA TTG GCT AGC ATA C 3'). The oligomers were cloned into the pcDNA6.2-GW/EmGFP-miR vector provided by the kit and transfected into M17 cells. Cells were subsequently selected and continuously maintained with $6 \mu \mathrm{g} / \mathrm{mL}$ Blasticidin $\mathrm{S} \mathrm{HCl}$ (Invitrogen $\mathrm{GmbH}$ ). Knockdown of endogenous RHOT1 was verified by Western blot analysis (Supplementary Fig. S1A). For our experiments, we choose the miRNA-2471, which showed the most efficient knockdown. As miRNA-2471 was designed to target the 5' UTR (untranslated region) of RHOT1 instead of the open reading frame, we were able to overexpress recombinant Miro1, using RHOT1 variants cloned into pcDNA3.1/V5-HisA (Invitrogen). M17 cells were transiently transfected with these constructs using TransIT ${ }^{\circledR}-2020$ transfection reagent (MIR 5400; Mirus Bio, LLC, Madison, WI). Overexpression was also verified by Western blot analysis (Supplementary Fig. S1B, C).

\section{Overexpression of Parkin in SH-SY5Y cells}

Neuroblastoma (SH-SY5Y) cells stably overexpressing Parkin were generated using lentiviral particles. To produce Parkin-expressing lentiviral particles, a cassette consisting of the open reading frame of the Parkin gene (NM_004562.3), the IRES sequence, and the Puromycin resistance gene were cloned into pLenti4/V5-DEST (ThermoFisher) plasmid (pLenti4-TH-IRES-Puromycin). Next, 293FT cells were cotransfected with pLenti-Parkin-IRES-Puromycin and the ViraPowerTM Packaging Mix (ThermoFisher) to generate a lentiviral stock. SH-SY5Y cells were transduced using lentiviral particles for $48 \mathrm{~h}$ and subsequently selected by using $2 \mu \mathrm{g} / \mathrm{mL}$ Puromycin (ThermoFisher) for $48 \mathrm{~h}$.

\section{Sodium dodecyl sulfate polyacrylamide gel electrophoresis and Western blot analysis}

Fibroblasts were lysed in RIPA buffer containing $1 \times$ complete protease inhibitor (Roche). Western blot analysis was performed with antibodies against Miro1 (WH0055288M1; Sigma-Aldrich, Munich, Germany), LC3-I/II (2775; Cell Signaling), Hsp60 (4870; Cell Signaling), Tom20 (sc-17764; Santa Cruz Biotechnologies), Rab9 (sc-74482; Santa Cruz Biotechnologies), MnSOD (ab13533; Abcam), anti-V5 (R960- 
25; Novex, R96125; Sigma-Aldrich), and $\beta$-actin (MA1-744; Thermo Scientific). Mitochondrial fractionation was performed as described previously (12).

\section{Live cell imaging}

Fibroblasts were seeded into Nunc ${ }^{\mathrm{TM}} \mathrm{Lab}^{\mathrm{T}} \mathrm{Tek}^{\mathrm{TM}}$ Chamber slides (Thermo Fisher Scientific) for imaging. Live cell imaging was performed with a Live Cell Microscope Axiovert 2000 with spinning disc, plan-apochromat objectives, and Hamamatsu camera C11440 (Carl Zeiss Microimaging $\mathrm{GmbH}$, Jena, Germany) in a humidified atmosphere containing $5 \% \mathrm{CO}_{2}$ at $37^{\circ} \mathrm{C}$.

For calcium imaging, fibroblasts were stained with $0.1 \mu M$ MitoTracker Deep Red FM (Thermo Fisher Scientific) in DMEM+/+ and Fluo4-AM (Thermo Fisher Scientific). During imaging, Fluo4-AM was present in the medium at a 1:1 (v/v) dilution. During imaging, cells were treated with $1 \mu M$ thapsigargin (Sigma-Aldrich). To test for the involvement of mitochondria in cytosolic calcium regulation, we incubated the cells with $10 \mu M$ Ru360 (Sigma-Aldrich). After treatment, time-laps imaging was continued for $10 \mathrm{~min}$ and images were acquired every $2 \mathrm{~s}$.

For analysis of colocalization of mitochondria and LC3 puncta, immortalized fibroblasts were transfected with mito-DsRed (5) and eGFP-LC3 (22) using TransIT-2020 transfection reagent (Mirus Bio, LLC). Cells were then treated with $25 \mu M \mathrm{CCCP}$ or $10 \mathrm{n} M$ bafilomycin $\mathrm{A}_{1}$ for 2 or $6 \mathrm{~h}$, respectively.

For analysis of autophagosome formation, cells were stained with $0.2 \mathrm{~m} M$ 18:1 NBD-PS (810198C; Sigma-Aldrich) for $30 \mathrm{~min}$ at $37^{\circ} \mathrm{C}$. Cells were subsequently starved in medium without FBS for $2 \mathrm{~h}$.

For colocalization analysis of mitochondria and ER, native fibroblasts were stained with $0.1 \mu M$ MitoTracker Deep Red FM and $1 \mu M$ ER-Tracker Green (Thermo Fisher Scientific) and imaged using the 368 or $488 \mathrm{~nm}$ laser.

For analysis of calcium-induced mitochondrial fragmentation, immortalized fibroblasts were stained with $0.1 \mu M$ MitoTracker Green FM (Thermo Fisher Scientific) for $45 \mathrm{~min}$ at $37^{\circ} \mathrm{C}$. After $1 \mathrm{~min}$ of imaging, cells were treated with $20 \mu M$ ionomycin (Sigma-Aldrich) and imaging was continued for $20 \mathrm{~min}$.

All image analysis was performed with MATLAB or ImageJ.

\section{Immunofluorescence stainings}

For colocalization analysis of mitochondria and ER, native fibroblasts were fixed with $4 \%$ paraformaldehyde for $15 \mathrm{~min}$ and then labeled with antibodies against Tom20 (sc-17764, dilution 1:500, secondary antibody:goat anti-mouse Alexa Fluor 647; Santa Cruz Biotechnologies; A-21235, dilution 1:1000; Life Technologies) and PDI (2446S, dilution 1:1000, secondary antibody:goat anti-rabbit Alexa Fluor 488; Cell Signaling Technology; A-1000, dilution 1:1000; Life Technologies).

\section{Measurement of ATP level}

Steady-state ATP levels were measured in immortalized fibroblasts $(n=500,000$ cells) grown under standard conditions. The quantification of total ATP levels was performed with the ATP Bioluminescence Assay Kit CLS II (Roche) according to the manufacturer's protocol in 96-well plates (Greiner Bio-One). The luminescence signal was detected with the Microplate Reader infinite M200Pro (TECAN).

\section{Statistics}

Statistical significance was determined using the GraphPad Prism 6.0 software. Statistical tests and $p$-values are indicated in the figure legends. To account for the small sample size used in this study, we employed nonparametric tests throughout. All experiments were independently repeated at least three times $(n$ represents the number of independent biological replicates).

\section{Acknowledgments}

We thank all patients and control individuals for their commitment and support for research. The KORA research platform (KORA, Cooperative Research in the Region of Augsburg) was initiated and financed by the Helmholtz Zentrum München-German Research Center for Environmental Health and funded by the German Federal Ministry of Education and Research and by the State of Bavaria, Germany. KORA research was supported within the Munich Center of Health Sciences (MC Health), LudwigMaximilians-Universität, as part of LMUinnovativ. The control fibroblasts were obtained from the Neuro-Biobank of the University of Tübingen, Tübingen, Germany. This biobank is supported by the local University, the Hertie Institute and the DZNE. The Miro1-WT/myc in the pRK5myc vector was a kind gift of Prof. Pontus Aspenström, Karolinska Institute, Sweden. R.K. has received research grants from Fonds National de la Recherche de Luxembourg (PEARL [FNR/P13/6682797/Krüger] and NCER-PD), the German Research Council (KR2119/8-1), the European Union's (EU) Horizon2020 research and innovation program (WIDESPREAD; CENTRE-PD; grant agreement No. 692320), and the Federal Ministry for Education and Research (BMBF; Mito-PD 031 A 430 A). R.K., A.G., E.G., M.S., and P.M. received funding from the CORE programme of the Fonds National de Recherche de Luxembourg (FNR, MiRisk-PD, C17/BM/11676395). A.S. was supported by the Fonds National de la Recherche through the C14/BM/ 7975668/CaSCAD grant and the National Biomedical Computation Resource (NBCR) through the NIH P41 GM103426 grant from the National Institutes of Health. E.G. received support from the Fonds Nationale de la Recherche, Luxembourg, as part of the project MitoPD, under the auspices of the bilateral e:Med program by the German Federal Ministry of Education and Research and the FNR (INTER/ BMBF/13/04). K.S.D. was supported by the German Research Council (DI 1386/2-1). J.C.F. acknowledges funding from the German Research Council, German Federal Ministry of Education and Research (BMBF) support code 031 A 430 A, DZNE, the University of Tubingen, and the EU Joint Programme-Neurodegenerative Disease Research (JPND) project. A.G. received funding from the Fonds National de la Recherche within the ATTRACT programme (FNR, Model IPD, FNR9631103). R.K., E.G., and P.M. received funding from the EU's Joint Program-Neurodegenerative Diseases Research (JPND; COURAGE-PD). A.R. was supported by the DFG (FOR2488). 


\section{Authors' Contributions}

Research project-conception: R.K., D.G., J.C.F., D.R., A.S., A.F.H., and A.G.; organization: D.G. and R.K.; execution: D.G., C.B.-E., M.E.B., F.M., J.B., J.G., D.S., M.S., P.L., E.G., P.M., K.S.D., and A.R. Statistical analysis-design and execution: D.G., M.E.B., P.A., E.G., P.M., K.S.D., and P.L.; review and critique: A.S., A.F.H., P.A., E.G., P.M., K.S.D., and D.R. Article-writing: D.G. and A.G.; review and critique: D.R., A.S., A.F.H., P.L., P.A., E.G., P.M., K.S.D., J.C.F., A.G., and R.K.

\section{Author Disclosure Statement}

R.K. received honoraria/travel grants from Abbvie, Zambon, and Medtronic and participated as site Principal Investigator for industry-sponsored clinical trials without receiving additional honoraria. All other authors have no competing financial interests.

\section{Supplementary Material}

Supplementary Figure S1

Supplementary Table S1

\section{References}

1. Adzhubei I, Jordan DM, and Sunyaev SR. Predicting functional effect of human missense mutations using PolyPhen-2. Curr Protoc Hum Genet Chapter 7: Unit7.20, 2013.

2. Anvret A, Ran C, Westerlund M, Sydow O, Willows T, Olson L, Galter D, and Belin AC. genetic screening of the mitochondrial Rho GTPases MIRO1 and MIRO2 in Parkinson's disease. Open Neurol J 6: 1-5, 2012.

3. Basso V, Marchesan E, Peggion C, Chakraborty J, von Stockum S, Giacomello M, Ottolini D, Debattisti V, Caicci F, Tasca E, Pegoraro V, Angelini C, Antonini A, Bertoli A, Brini M, and Ziviani E. Regulation of ER-mitochondria contacts by Parkin via Mfn2. Pharmacol Res 138: 43-56, 2018.

4. Birsa N, Norkett R, Wauer T, Mevissen TET, Wu HC, Foltynie T, Bhatia K, Hirst WD, Komander D, PlunFavreau H, and Kittler JT. Lysine 27 ubiquitination of the mitochondrial transport protein miro is dependent on serine 65 of the parkin ubiquitin ligase. J Biol Chem 289: 1456914582, 2014.

5. Burbulla LF, Schelling C, Kato H, Rapaport D, Woitalla D, Schiesling C, Schulte C, Sharma M, Illig T, Bauer P, Jung S, Nordheim A, Schöls L, Riess O, and Krüger R. Dissecting the role of the mitochondrial chaperone mortalin in Parkinson's disease: functional impact of disease-related variants on mitochondrial homeostasis. Hum Mol Genet 19: 4437-4452, 2010.

6. This reference has been deleted

7. Calì T, Ottolini D, Negro A, and Brini M. Enhanced parkin levels favor ER-mitochondria crosstalk and guarantee $\mathrm{Ca}(2+)$ transfer to sustain cell bioenergetics. Biochim Biophys Acta 1832: 495-508, 2013.

8. Chan NC, Salazar AM, Pham AH, Sweredoski MJ, Kolawa NJ, Graham RLJ, Hess S, and Chan DC. Broad activation of the ubiquitin-proteasome system by Parkin is critical for mitophagy. Hum Mol Genet 20: 1726-1737, 2011.

9. Chang KT, Niescier RF, and Min K-T. Mitochondrial matrix $\mathrm{Ca}^{2+}$ as an intrinsic signal regulating mitochondrial motility in axons. Proc Natl Acad Sci U S A 108: 1545615461, 2011.

10. Chun S and Fay JC. Identification of deleterious mutations within three human genomes. Genome Res 19: 1553-1561, 2009.

11. Dong C, Wei P, Jian X, Gibbs R, Boerwinkle E, Wang K, and Liu X. Comparison and integration of deleteriousness prediction methods for nonsynonymous SNVs in whole exome sequencing studies. Hum Mol Genet 24: 2125-2137, 2015.

12. Grünewald A, Gegg ME, Taanman J-W, King RH, Kock N, Klein C, and Schapira AH. Differential effects of PINK1 nonsense and missense mutations on mitochondrial function and morphology. Exp Neurol 219: 266-273, 2009.

13. Guo X, Macleod GT, Wellington A, Hu F, Panchumarthi S, Schoenfield M, Marin L, Charlton MP, Atwood HL, and Zinsmaier KE. The GTPase dMiro is required for axonal transport of mitochondria to drosophila synapses. Neuron 47: 379-393, 2005.

14. Hailey DW, Rambold AS, Satpute-Krishnan P, Mitra K, Sougrat R, Kim PK, and Lippincott-Schwartz J. Mitochondria supply membranes for autophagosome biogenesis during starvation. Cell 141: 656-667, 2010.

15. Hobert MA, Niebler R, Meyer SI, Brockmann K, Becker C, Huber H, Gaenslen A, Godau J, Eschweiler GW, Berg D, and Maetzler W. Poor trail making test performance is directly associated with altered dual task prioritization in the elderly-baseline results from the TREND study. PLoS One 6: e27831, 2011.

16. Hsieh C-H, Shaltouki A, Gonzalez AE, Bettencourt da Cruz A, Burbulla LF, St Lawrence E, Schüle B, Krainc D, Palmer TD, and Wang X. Functional impairment in miro degradation and mitophagy is a shared feature in familial and sporadic Parkinson's disease. Cell Stem Cell 19: 709-724, 2016.

17. This reference has been deleted.

18. Kirichok Y, Krapivinsky G, and Clapham DE. The mitochondrial calcium uniporter is a highly selective ion channel. Nature 427: 360-364, 2004.

19. Klionsky DJ, Abdelmohsen K, Abe A, Abedin MJ, Abeliovich $\mathrm{H}$, Arozena AA, Adachi $\mathrm{H}$, Adams CM, Adams PD, Adeli K, Adhihetty PJ, Adler SG, Agam G, Agarwal R, Aghi MK, Agnello M, Agostinis P, Aguilar P V., AguirreGhiso J, Airoldi EM, Ait-Si-Ali S, Akematsu T, Akporiaye ET, Al-Rubeai M, Albaiceta GM, Albanese C, Albani D, Albert ML, Aldudo J, Algül H, Alirezaei M, Alloza I, Almasan A, Almonte-Beceril M, Alnemri ES, Alonso C, Altan-Bonnet N, Altieri DC, Alvarez S, Alvarez-Erviti L, Alves S, Amadoro G, Amano A, Amantini C, Ambrosio S, Amelio I, Amer AO, Amessou M, Amon A, An Z, Anania FA, Andersen SU, Andley UP, Andreadi CK, AndrieuAbadie N, Anel A, Ann DK, Anoopkumar-Dukie S, Antonioli M, Aoki H, Apostolova N, Aquila S, Aquilano K, Araki K, Arama E, Aranda A, Araya J, Arcaro A, Arias E, Arimoto H, Ariosa AR, Armstrong JL, Arnould T, Arsov I, Asanuma K, Askanas V, Asselin E, Atarashi R, Atherton SS, Atkin JD, Attardi LD, Auberger P, Auburger G, Aurelian L, Autelli R, Avagliano L, Avantaggiati ML, Avrahami L, Azad N, Awale S, Bachetti T, Backer JM, Bae DH, Bae JS, Bae ON, Bae SH, Baehrecke EH, Baek SH, Baghdiguian S, Bagniewska-Zadworna A, Bai H, Bai J, Bai XY, Bailly Y, Balaji KN, Balduini W, Ballabio A, Balzan R, Banerjee R, Bánhegyi G, Bao H, Barbeau B, Barrachina MD, Barreiro E, Bartel B, Bartolomé A, Bassham DC, Bassi MT, Bast RC, Basu A, Batista MT, Batoko H, Battino M, Bauckman K, Baumgarner BL, Bayer KU, Beale R, 
Beaulieu JF, Beck GR, Becker C, Beckham JD, Bédard PA, Bednarski PJ, Begley TJ, Behl C, Behrends C, Behrens GMN, Behrns KE, Bejarano E, Belaid A, Belleudi F, Bénard G, Berchem G, Bergamaschi D, Bergami M, Berkhout B, Berliocchi L, Bernard A, Bernard M, Bernassola F, Bertolotti A, Bess AS, Besteiro S, Bettuzzi S, Bhalla S, Bhattacharyya S, Bhutia SK, Biagosch C, Bianchi MW, Biard-Piechaczyk M, Billes V, Bincoletto C, Bingol B, Bird SW, Bitoun M, Bjedov I, Blackstone C, Blanc L, Blanco GA, Blomhoff HK, Boada-Romero E, Böckler S, Boes M, Boesze-Battaglia K, Boise LH, Bolino A, Boman A, Bonaldo P, Bordi M, Bosch J, Botana LM, Botti J, Bou G, Bouché M, Bouchecareilh M, Boucher MJ, Boulton ME, Bouret SG, Boya P, Boyer-Guittaut M, Bozhkov PV, Brady $\mathrm{N}$, Braga VMM, Brancolini C, Braus GH, Bravosan-Pedro JM, Brennan LA, Bresnick EH, Brest P, Bridges D, Bringer MA, Brini M, Brito GC, Brodin B, Brookes PS, Brown EJ, Brown K, Broxmeyer HE, Bruhat A, Brum PC, Brumell JH, Brunetti-Pierri N, Bryson-Richardson RJ, Buch S, Buchan AM, Budak H, Bulavin DV, Bultman SJ, Bultynck G, Bumbasirevic V, Burelle Y, Burke RE, Burmeister M, Bütikofer P, Caberlotto L, Cadwell K, Cahova M, Cai D, Cai J, Cai Q, Calatayud S, Camougrand N, Campanella M, Campbell GR, Campbell M, Campello S, Candau R, Caniggia I, Cantoni L, Cao L, Caplan AB, Caraglia M, Cardinali C, Cardoso SM, Carew JS, Carleton LA, Carlin CR, Carloni S, Carlsson SR, Carmona-Gutierrez D, Carneiro LAM, Carnevali O, Carra S, Carrier A, Carroll B, Casas C, Casas J, Cassinelli G, Castets P, Castro-Obregon S, Cavallini G, Ceccherini I, Cecconi F, Cederbaum AI, Ceña V, Cenci S, Cerella C, Cervia D, Cetrullo S, Chaachouay H, Chae HJ, Chagin AS, Chai CY, Chakrabarti G, Chamilos G, Chan EYW, Chan MTV, Chandra D, Chandra P, Chang CP, Chang RCC, Chang TY, Chatham JC, Chatterjee S, Chauhan S, Che Y, Cheetham ME, Cheluvappa R, Chen CJ, Chen G, Chen GC, Chen G, Chen H, Chen JW, Chen JK, Chen M, Chen M, Chen P, Chen Q, Chen Q, Chen SD, Chen S, Chen SSL, Chen W, Chen WJ, Chen WQ, Chen W, Chen X, Chen YH, Chen YG, Chen Y, Chen Y, Chen Y, Chen YJ, Chen YQ, Chen Y, Chen Z, Chen Z, Cheng A, Cheng CHK, Cheng H, Cheong H, Cherry S, Chesney J, Cheung CHA, Chevet E, Chi HC, Chi SG, Chiacchiera F, Chiang HL, Chiarelli R, Chiariello M, Chieppa M, Chin LS, Chiong M, Chiu GNC, Cho DH, Cho SG, Cho WC, Cho YY, Cho YS, Choi AMK, Choi EJ, Choi EK, Choi J, Choi ME, Choi SI, Chou TF, Chouaib S, Choubey D, Choubey V, Chow KC, Chowdhury K, Chu CT, Chuang TH, Chun T, Chung H, Chung T, Chung YL, Chwae YJ, Cianfanelli V, Ciarcia R, Ciechomska IA, Ciriolo MR, Cirone M, Claerhout S, Clague MJ, Clària J, Clarke PGH, Clarke R, Clementi E, Cleyrat C, Cnop M, Coccia EM, Cocco T, Codogno P, Coers J, Cohen EEW, Colecchia D, Coletto L, Coll NS, Colucci-Guyon E, Comincini S, Condello M, Cook KL, Coombs GH, Cooper CD, Cooper JM, Coppens I, Corasaniti MT, Corazzari M, Corbalan R, Corcelle-Termeau E, Cordero MD, Corral-Ramos C, Corti O, Cossarizza A, Costelli P, Costes S, Cotman SL, CotoMontes A, Cottet S, Couve E, Covey LR, Cowart LA, Cox JS, Coxon FP, Coyne CB, Cragg MS, Craven RJ, Crepaldi T, Crespo JL, Criollo A, Crippa V, Cruz MT, Cuervo AM, Cuezva JM, Cui T, Cutillas PR, Czaja MJ, Czyzyk-Krzeska MF, Dagda RK, Dahmen U, Dai C, Dai W, Dai Y, Dalby KN, Valle LD, Dalmasso G, D'amelio M, Damme M, Darfeuille-Michaud A, Dargemont C, Darley-Usmar VM,
Dasarathy S, Dasgupta B, Dash S, Dass CR, Davey HM, Davids LM, Dávila D, Davis RJ, Dawson TM, Dawson VL, Daza P, de Belleroche J, de Figueiredo P, de Figueiredo RCBQ, de la Fuente J, De Martino L, De Matteis A, De Meyer GRY, De Milito A, De Santi M, de Souza W, De Tata V, De Zio D, Debnath J, Dechant R, Decuypere JP, Deegan S, Dehay B, Del Bello B, Del Re DP, DelageMourroux R, Delbridge LMD, Deldicque L, DelormeAxford E, Deng Y, Dengjel J, Denizot M, Dent P, Der CJ, Deretic V, Derrien B, Deutsch E, Devarenne TP, Devenish RJ, Di Bartolomeo S, Di Daniele N, Di Domenico F, Di Nardo A, Di Paola S, Di Pietro A, Di Renzo L, Di Antonio A, Díaz-Araya G, Díaz-Laviada I, Diaz-Meco MT, DiazNido J, Dickey CA, Dickson RC, Diederich M, Digard P, Dikic I, Dinesh-Kumar SP, Ding C, Ding WX, Ding Z, Dini L, Distler JHW, Diwan A, Djavaheri-Mergny M, Dmytruk K, Dobson RCJ, Doetsch V, Dokladny K, Dokudovskaya S, Donadelli M, Dong XC, Dong X, Dong Z, Donohue TM, Jr., Doran KS, D'orazi G, Dorn GW, Dosenko V, Dridi S, Drucker L, Du J, Du LL, Du L, du Toit A, Dua P, Duan L, Duann P, Dubey VK, Duchen MR, Duchosal MA, Duez H, Dugail I, Dumit VI, Duncan MC, Dunlop EA, Dunn WA, Dupont N, Dupuis L, Durán RV, Durcan TM, DuvezinCaubet S, Duvvuri U, Eapen V, Ebrahimi-Fakhari D, Echard A, Eckhart L, Edelstein CL, Edinger AL, Eichinger L, Eisenberg T, Eisenberg-Lerner A, Eissa NT, El-Deiry WS, El-Khoury V, Elazar Z, Eldar-Finkelman H, Elliott $\mathrm{CJH}$, Emanuele E, Emmenegger U, Engedal N, Engelbrecht AM, Engelender S, Enserink JM, Erdmann R, Erenpreisa J, Eri R, Eriksen JL, Erman A, Escalante R, Eskelinen EL, Espert L, Esteban-Martínez L, Evans TJ, Fabri M, Fabrias G, Fabrizi C, Facchiano A, Færgeman NJ, Faggioni A, Fairlie WD, Fan C, Fan D, Fan J, Fang S, Fanto M, Fanzani A, Farkas T, Faure M, Favier FB, Fearnhead H, Federici M, Fei E, Felizardo TC, Feng H, Feng Y, Feng Y, Ferguson TA, Fernández ÁF, FernandezBarrena MG, Fernandez-Checa JC, Fernández-López A, Fernandez-Zapico ME, Feron O, Ferraro E, Ferreira-Halder CV, Fesus L, Feuer R, Fiesel FC, Filippi-Chiela EC, Filomeni G, Fimia GM, Fingert JH, Finkbeiner S, Finkel T, Fiorito F, Fisher PB, Flajolet M, Flamigni F, Florey O, Florio S, Floto RA, Folini M, Follo C, Fon EA, Fornai F, Fortunato F, Fraldi A, Franco R, Francois A, François A, Frankel LB, Fraser IDC, Frey N, Freyssenet DG, Frezza C, Friedman SL, Frigo DE, Fu D, Fuentes JM, Fueyo J, Fujitani Y, Fujiwara Y, Fujiya M, Fukuda M, Fulda S, Fusco C, Gabryel B, Gaestel M, Gailly P, Gajewska M, Galadari S, Galili G, Galindo I, Galindo MF, Galliciotti G, Galluzzi L, Galluzzi L, Galy V, Gammoh N, Gandy S, Ganesan AK, Ganesan S, Ganley IG, Gannagé M, Gao FB, Gao F, Gao JX, Nannig LG, Véscovi EG, Garcia-Macía M, Garcia-Ruiz C, Garg AD, Garg PK, Gargini R, Gassen NC, Gatica D, Gatti E, Gavard J, Gavathiotis E, Ge L, Ge P, Ge S, Gean PW, Gelmetti V, Genazzani AA, Geng J, Genschik P, Gerner L, Gestwicki JE, Gewirtz DA, Ghavami S, Ghigo E, Ghosh D, Giammarioli AM, Giampieri F, Giampietri C, Giatromanolaki A, Gibbings DJ, Gibellini L, Gibson SB, Ginet V, Giordano A, Giorgini F, Giovannetti E, Girardin SE, Gispert S, Giuliano S, Gladson CL, Glavic A, Gleave M, Godefroy N, Gogal RM, Gokulan K, Goldman GH, Goletti D, Goligorsky MS, Gomes AV, Gomes LC, Gomez H, Gomez-Manzano C, Gómez-Sánchez R, Gonçalves DAP, Goncu E, Gong Q, Gongora C, Gonzalez CB, Gonzalez-Alegre P, Gonzalez-Cabo P, González-Polo RA, 
Goping IS, Gorbea C, Gorbunov NV, Goring DR, Gorman AM, Gorski SM, Goruppi S, Goto-Yamada S, Gotor C, Gottlieb RA, Gozes I, Gozuacik D, Graba Y, Graef M, Granato GE, Grant GD, Grant S, Gravina GL, Green DR, Greenhough A, Greenwood MT, Grimaldi B, Gros F, Grose C, Groulx JF, Gruber F, Grumati P, Grune T, Guan JL, Guan KL, Guerra B, Guillen C, Gulshan K, Gunst J, Guo C, Guo L, Guo M, Guo W, Guo XG, Gust AA, Gustafsson ÅB, Gutierrez E, Gutierrez MG, Gwak HS, Haas A, Haber JE, Hadano S, Hagedorn M, Hahn DR, Halayko AJ, HamacherBrady A, Hamada K, Hamai A, Hamann A, Hamasaki M, Hamer I, Hamid Q, Hammond EM, Han F, Han W, Handa JT, Hanover JA, Hansen M, Harada M, Harhaji-Trajkovic L, Harper JW, Harrath AH, Harris AL, Harris J, Hasler U, Hasselblatt P, Hasui K, Hawley RG, Hawley TS, He C, He CY, He F, He G, He RR, He XH, He YW, He YY, Heath JK, Hébert MJ, Heinzen RA, Helgason GV, Hensel M, Henske EP, Her C, Herman PK, Hernández A, Hernandez C, Hernández-Tiedra S, Hetz C, Hiesinger PR, Higaki K, Hilfiker S, Hill BG, Hill JA, Hill WD, Hino K, Hofius D, Hofman P, Höglinger GU, Höhfeld J, Holz MK, Hong Y, Hood DA, Hoozemans JJM, Hoppe T, Hsu C, Hsu CY, Hsu LC, Hu D, Hu G, Hu HM, Hu H, Hu MC, Hu YC, Hu ZW, Hua F, Hua Y, Huang C, Huang HL, Huang KH, Huang KY, Huang S, Huang S, Huang WP, Huang YR, Huang Y, Huang Y, Huber TB, Huebbe P, Huh WK, Hulmi JJ, Hur GM, Hurley JH, Husak Z, Hussain SNA, Hussain S, Hwang JJ, Hwang S, Hwang TIS, Ichihara A, Imai Y, Imbriano C, Inomata M, Into $\mathrm{T}$, Iovane $\mathrm{V}$, Iovanna JL, Iozzo R V., Ip $\mathrm{NY}$, Irazoqui JE, Iribarren $\mathrm{P}$, Isaka $\mathrm{Y}$, Isakovic $\mathrm{AJ}$, Ischiropoulos $\mathrm{H}$, Isenberg JS, Ishaq M, Ishida $\mathrm{H}$, Ishii I, Ishmael JE, Isidoro $\mathrm{C}$, Isobe $\mathrm{KI}$, Isono $\mathrm{E}$, IssazadehNavikas S, Itahana K, Itakura E, Ivanov AI, Iyer AKV, Izquierdo JM, Izumi $Y$, Izzo $V$, Jäättelä $M$, Jaber $N$, Jackson DJ, Jackson WT, Jacob TG, Jacques TS, Jagannath C, Jain A, Jana NR, Jang BK, Jani A, Janji B, Jannig PR, Jansson PJ, Jean S, Jendrach M, Jeon JH, Jessen N, Jeung EB, Jia K, Jia L, Jiang H, Jiang H, Jiang L, Jiang T, Jiang X, Jiang X, Jiang Y, Jiang Y, Jiménez A, Jin C, Jin H, Jin L, Jin M, Jin S, Jinwal UK, Jo EK, Johansen T, Johnson DE, Johnson GVW, Johnson JD, Jonasch E, Jones C, Joosten LAB, Jordan J, Joseph AM, Joseph B, Joubert AM, Ju D, Ju J, Juan HF, Juenemann K, Juhász G, Jung HS, Jung JU, Jung YK, Jungbluth H, Justice MJ, Jutten B, Kaakoush NO, Kaarniranta K, Kaasik A, Kabuta T, Kaeffer B, Kågedal K, Kahana A, Kajimura S, Kakhlon O, Kalia M, Kalvakolanu D V., Kamada Y, Kambas K, Kaminskyy VO, Kampinga HH, Kandouz M, Kang C, Kang R, Kang TC, Kanki T, Kanneganti TD, Kanno H, Kanthasamy AG, Kantorow M, Kaparakis-Liaskos M, Kapuy O, Karantza V, Karim MR, Karmakar P, Kaser A, Kaushik S, Kawula T, Kaynar AM, Ke PY, Ke ZJ, Kehrl JH, Keller KE, Kemper JK, Kenworthy AK, Kepp O, Kern A, Kesari S, Kessel D, Ketteler R, Kettelhut I do C, Khambu B, Khan MM, Khandelwal VKM, Khare S, Kiang JG, Kiger AA, Kihara A, Kim AL, Kim CH, Kim DR, Kim DH, Kim EK, Kim HY, Kim HR, Kim JS, Kim JH, Kim JC, Kim JH, Kim KW, Kim MD, Kim MM, Kim PK, Kim SW, Kim SY, Kim YS, Kim Y, Kimchi A, Kimmelman AC, Kimura T, King JS, Kirkegaard K, Kirkin V, Kirshenbaum LA, Kishi S, Kitajima Y, Kitamoto K, Kitaoka Y, Kitazato K, Kley RA, Klimecki WT, Klinkenberg M, Klucken J, Knævelsrud H, Knecht E, Knuppertz L, Ko JL, Kobayashi S, Koch JC, Koechlin-Ramonatxo C, Koenig U, Koh YH, Köhler K,
Kohlwein SD, Koike M, Komatsu M, Kominami E, Kong D, Kong HJ, Konstantakou EG, Kopp BT, Korcsmaros T, Korhonen L, Korolchuk VI, Koshkina N V., Kou Y, Koukourakis MI, Koumenis C, Kovács AL, Kovács T, Kovacs WJ, Koya D, Kraft C, Krainc D, Kramer H, KravicStevovic T, Krek W, Kretz-Remy C, Krick R, Krishnamurthy M, Kriston-Vizi J, Kroemer G, Kruer MC, Kruger R, Ktistakis NT, Kuchitsu K, Kuhn C, Kumar AP, Kumar A, Kumar A, Kumar D, Kumar D, Kumar R, Kumar S, Kundu M, Kung HJ, Kuno A, Kuo SH, Kuret J, Kurz T, Kwok T, Kwon TK, Kwon YT, Kyrmizi I, La Spada AR, Lafont F, Lahm T, Lakkaraju A, Lam T, Lamark T, Lancel S, Landowski TH, Lane DJR, Lane JD, Lanzi C, Lapaquette P, Lapierre LR, Laporte J, Laukkarinen J, Laurie GW, Lavandero S, Lavie L, Lavoie MJ, Law BYK, Law HKW, Law KB, Layfield R, Lazo PA, Le Cam L, Le Roch KG, Le Stunff H, Leardkamolkarn V, Lecuit M, Lee BH, Lee $\mathrm{CH}$, Lee EF, Lee GM, Lee HJ, Lee H, Lee JK, Lee J, Lee JH, Lee JH, Lee M, Lee MS, Lee PJ, Lee SW, Lee SJ, Lee SJ, Lee SY, Lee SH, Lee SS, Lee SJ, Lee S, Lee YR, Lee YJ, Lee YH, Leeuwenburgh C, Lefort S, Legouis R, Lei J, Lei QY, Leib DA, Leibowitz G, Lekli I, Lemaire SD, Lemasters JJ, Lemberg MK, Lemoine A, Leng S, Lenz G, Lenzi P, Lerman LO, Barbato DL, Leu JIJ, Leung HY, Levine B, Lewis PA, Lezoualch F, Li C, Li F, Li FJ, Li J, Li K, Li L, Li M, Li Q, Li R, Li S, Li W, Li X, Li Y, Lian J, Liang C, Liang Q, Liao Y, Liberal J, Liberski PP, Lie P, Lieberman AP, Lim HJ, Lim KL, Lim K, Lima RT, Lin CS, Lin CF, Lin F, Lin F, Lin FC, Lin K, Lin KH, Lin PH, Lin $\mathrm{T}$, Lin WW, Lin YS, Lin Y, Linden R, Lindholm D, Lindqvist LM, Lingor P, Linkermann A, Liotta LA, Lipinski MM, Lira VA, Lisanti MP, Liton PB, Liu B, Liu C, Liu CF, Liu F, Liu HJ, Liu J, Liu JJ, Liu JL, Liu K, Liu L, Liu L, Liu Q, Liu RY, Liu S, Liu S, Liu W, Liu X De, Liu X, Liu XH, Liu X, Liu X, Liu X, Liu Y, Liu Y, Liu Z, Liu Z, Liuzzi JP, Lizard G, Ljujic M, Lodhi IJ, Logue SE, Lokeshwar BL, Long YC, Lonial S, Loos B, López-Otín C, López-Vicario C, Lorente M, Lorenzi PL, Lõrincz P, Los M, Lotze MT, Lovat PE, Lu B, Lu B, Lu J, Lu Q, Lu SM, Lu S, Lu Y, Luciano F, Luckhart S, Lucocq JM, Ludovico P, Lugea A, Lukacs NW, Lum JJ, Lund AH, Luo H, Luo J, Luo S, Luparello C, Lyons T, Ma J, Ma Y, Ma Y, Ma Z, Machado J, Machado-Santelli GM, Macian F, MacIntosh GC, MacKeigan JP, Macleod KF, MacMicking JD, MacMillan-Crow LA, Madeo F, Madesh M, MadrigalMatute J, Maeda A, Maeda T, Maegawa G, Maellaro E, Maes H, Magariños M, Maiese K, Maiti TK, Maiuri L, Maiuri MC, Maki CG, Malli R, Malorni W, Maloyan A, Mami-Chouaib F, Man N, Mancias JD, Mandelkow EM, Mandell MA, Manfredi AA, Manié SN, Manzoni C, Mao K, Mao Z, Mao ZW, Marambaud P, Marconi AM, Marelja Z, Marfe G, Margeta M, Margittai E, Mari M, Mariani F V., Marin C, Marinelli S, Mariño G, Markovic I, Marquez R, Martelli AM, Martens S, Martin KR, Martin SJ, Martin S, Martin-Acebes MA, Martín-Sanz P, Martinand-Mari C, Martinet W, Martinez J, Martinez-Lopez N, MartinezOutschoorn U, Martínez-Velázquez M, Martinez-Vicente M, Martins WK, Mashima H, Mastrianni JA, Matarese G, Matarrese P, Mateo R, Matoba S, Matsumoto N, Matsushita T, Matsuura A, Matsuzawa T, Mattson MP, Matus S, Maugeri N, Mauvezin C, Mayer A, Maysinger D, Mazzolini GD, McBrayer MK, McCall K, McCormick C, McInerney GM, McIver SC, McKenna S, McMahon JJ, McNeish IA, Mechta-Grigoriou F, Medema JP, Medina 
DL, Megyeri K, Mehrpour M, Mehta JL, Mei Y, Meier UC, Meijer AJ, Meléndez A, Melino G, Melino S, de Melo EJT, Mena MA, Meneghini MD, Menendez JA, Menezes R, Meng L, Meng LH, Meng S, Menghini R, Menko AS, Menna-Barreto RFS, Menon MB, Meraz-Ríos MA, Merla G, Merlini L, Merlot AM, Meryk A, Meschini S, Meyer JN, Mi MT, Miao CY, Micale L, Michaeli S, Michiels C, Migliaccio AR, Mihailidou AS, Mijaljica D, Mikoshiba K, Milan E, Miller-Fleming L, Mills GB, Mills IG, Minakaki G, Minassian BA, Ming XF, Minibayeva F, Minina EA, Mintern JD, Minucci S, Miranda-Vizuete A, Mitchell CH, Miyamoto S, Miyazawa K, Mizushima N, Mnich K, Mograbi B, Mohseni S, Moita LF, Molinari M, Molinari M, Møller AB, Mollereau B, Mollinedo F, Mongillo M, Monick MM, Montagnaro S, Montell C, Moore DJ, Moore MN, Mora-Rodriguez R, Moreira PI, Morel E, Morelli MB, Moreno S, Morgan MJ, Moris A, Moriyasu Y, Morrison JL, Morrison LA, Morselli E, Moscat J, Moseley PL, Mostowy S, Motori E, Mottet D, Mottram JC, Moussa CEH, Mpakou VE, Mukhtar H, Levy JMM, Muller S, Muñoz-Moreno R, Muñoz-Pinedo C, Münz C, Murphy ME, Murray JT, Murthy A, Mysorekar IU, Nabi IR, Nabissi M, Nader GA, Nagahara Y, Nagai Y, Nagata K, Nagelkerke A, Nagy P, Naidu SR, Nair S, Nakano H, Nakatogawa H, Nanjundan M, Napolitano G, Naqvi NI, Nardacci R, Narendra DP, Narita M, Nascimbeni AC, Natarajan R, Navegantes LC, Nawrocki ST, Nazarko TY, Nazarko VY, Neill T, Neri LM, Netea MG, Netea-Maier RT, Neves BM, Ney PA, Nezis IP, Nguyen HTT, Nguyen HP, Nicot AS, Nilsen H, Nilsson P, Nishimura M, Nishino I, Niso-Santano M, Niu H, Nixon RA, Njar VCO, Noda T, Noegel AA, Nolte EM, Norberg E, Norga KK, Noureini SK, Notomi S, Notterpek L, Nowikovsky $K$, Nukina $\mathrm{N}$, Nürnberger T, O'Donnell VB, O'Donovan T, O’Dwyer PJ, Oehme I, Oeste CL, Ogawa M, Ogretmen B, Ogura Y, Oh YJ, Ohmuraya M, Ohshima T, Ojha R, Okamoto K, Okazaki T, Oliver FJ, Ollinger K, Olsson S, Orban DP, Ordonez P, Orhon I, Orosz L, O'rourke EJ, Orozco H, Ortega AL, Ortona E, Osellame LD, Oshima J, Oshima S, Osiewacz HD, Otomo T, Otsu K, Ou JHJ, Outeiro TF, Ouyang DY, Ouyang H, Overholtzer M, Ozbun MA, Ozdinler PH, Ozpolat B, Pacelli C, Paganetti P, Page G, Pages G, Pagnini U, Pajak B, Pak SC, Pakos-Zebrucka K, Pakpour N, Palková Z, Palladino F, Pallauf K, Pallet N, Palmieri M, Paludan SR, Palumbo C, Palumbo S, Pampliega O, Pan H, Pan W, Panaretakis T, Pandey A, Pantazopoulou A, Papackova Z, Papademetrio DL, Papassideri I, Papini A, Parajuli N, Pardo J, Parekh VV, Parenti G, Park JI, Park J, Park OK, Parker R, Parlato R, Parys JB, Parzych KR, Pasquet JM, Pasquier B, Pasumarthi KBS, Patschan D, Pattingre S, Pattison S, Pause A, Pavenstädt H, Pavone F, Pedrozo Z, Peña FJ, Peñalva MA, Pende M, Peng J, Penna F, Penninger JM, Pensalfini A, Pepe S, Pereira GJS, Pereira PC, de la Cruz VP, PérezPérez ME, Pérez-Rodríguez D, Pérez-Sala D, Perier C, Perl A, Perlmutter DH, Perrotta I, Pervaiz S, Pesonen M, Pessin JE, Peters GJ, Petersen M, Petrache I, Petrof BJ, Petrovski G, Phang JM, Piacentini M, Pierdominici M, Pierre P, Pierrefite-Carle V, Pietrocola F, Pimentel-Muiños FX, Pinar M, Pineda B, Pinkas-Kramarski R, Pinti M, Pinton P, Piperdi B, Piret JM, Platanias LC, Platta HW, Plowey ED, Pöggeler S, Poirot M, Polčic P, Poletti A, Poon AH, Popelka H, Popova B, Poprawa I, Poulose SM, Poulton J, Powers SK, Powers T, Pozuelo-Rubio M, Prak K, Prange R, Prescott M, Priault M, Prince S, Proia RL, Proikas-
Cezanne T, Prokisch H, Promponas VJ, Przyklenk K, Puertollano R, Pugazhenthi S, Puglielli L, Pujol A, Puyal J, Pyeon D, Qi X, Qian W Bin, Qin ZH, Qiu Y, Qu Z, Quadrilatero J, Quinn F, Raben N, Rabinowich H, Radogna F, Ragusa MJ, Rahmani M, Raina K, Ramanadham S, Ramesh R, Rami A, Randall-Demllo S, Randow F, Rao H, Rao VA, Rasmussen BB, Rasse TM, Ratovitski EA, Rautou PE, Ray SK, Razani B, Reed BH, Reggiori F, Rehm M, Reichert AS, Rein T, Reiner DJ, Reits E, Ren J, Ren X, Renna M, Reusch JEB, Revuelta JL, Reyes L, Rezaie AR, Richards RI, Richardson DR, Richetta C, Riehle MA, Rihn BH, Rikihisa Y, Riley BE, Rimbach G, Rippo MR, Ritis K, Rizzi F, Rizzo E, Roach PJ, Robbins J, Roberge M, Roca G, Roccheri MC, Rocha S, Rodrigues CMP, Rodríguez CI, de Cordoba SR, Rodriguez-Muela N, Roelofs J, Rogov VV, Rohn TT, Rohrer B, Romanelli D, Romani L, Romano PS, Roncero MIG, Rosa JL, Rosello A, Rosen K V., Rosenstiel P, Rost-Roszkowska M, Roth KA, Roué G, Rouis M, Rouschop KM, Ruan DT, Ruano D, Rubinsztein DC, Rucker EB, Rudich A, Rudolf E, Rudolf R, Ruegg MA, Ruiz-Roldan C, Ruparelia AA, Rusmini P, Russ DW, Russo GL, Russo G, Russo R, Rusten TE, Ryabovol V, Ryan KM, Ryter SW, Sabatini DM, Sacher M, Sachse C, Sack MN, Sadoshima J, Saftig P, Sagi-Eisenberg R, Sahni S, Saikumar P, Saito T, Saitoh T, Sakakura K, SakohNakatogawa M, Sakuraba Y, Salazar-Roa M, Salomoni P, Saluja AK, Salvaterra PM, Salvioli R, Samali A, Sanchez AMJ, Sánchez-Alcázar JA, Sanchez-Prieto R, Sandri M, Sanjuan MA, Santaguida S, Santambrogio L, Santoni G, Dos Santos CN, Saran S, Sardiello M, Sargent G, Sarkar P, Sarkar S, Sarrias MR, Sarwal MM, Sasakawa C, Sasaki M, Sass M, Sato K, Sato M, Satriano J, Savaraj N, Saveljeva S, Schaefer L, Schaible UE, Scharl M, Schatzl HM, Schekman R, Scheper W, Schiavi A, Schipper HM, Schmeisser H, Schmidt J, Schmitz I, Schneider BE, Schneider EM, Schneider JL, Schon EA, Schönenberger MJ, Schönthal AH, Schorderet DF, Schröder B, Schuck S, Schulze RJ, Schwarten M, Schwarz TL, Sciarretta S, Scotto K, Scovassi AI, Screaton RA, Screen M, Seca H, Sedej S, Segatori L, Segev N, Seglen PO, Seguí-Simarro JM, Segura-Aguilar J, Seiliez I, Seki E, Sell C, Semenkovich CF, Semenza GL, Sen U, Serra AL, Serrano-Puebla A, Sesaki H, Setoguchi T, Settembre C, Shacka JJ, Shajahan-Haq AN, Shapiro IM, Sharma S, She H, Shen CKJ, Shen CC, Shen HM, Shen S, Shen W, Sheng R, Sheng X, Sheng ZH, Shepherd TG, Shi J, Shi Q, Shi Q, Shi Y, Shibutani S, Shibuya K, Shidoji Y, Shieh JJ, Shih CM, Shimada Y, Shimizu S, Shin DW, Shinohara ML, Shintani M, Shintani T, Shioi T, Shirabe K, Shiri-Sverdlov R, Shirihai O, Shore GC, Shu CW, Shukla D, Sibirny AA, Sica V, Sigurdson CJ, Sigurdsson EM, Sijwali PS, Sikorska B, Silveira WA, Silvente-Poirot S, Silverman GA, Simak J, Simmet T, Simon AK, Simon HU, Simone C, Simons M, Simonsen A, Singh R, Singh S V., Singh SK, Sinha D, Sinha S, Sinicrope FA, Sirko A, Sirohi K, Sishi BJN, Sittler A, Siu PM, Sivridis E, Skwarska A, Slack R, Slaninová I, Slavov N, Smaili SS, Smalley KSM, Smith DR, Soenen SJ, Soleimanpour SA, Solhaug A, Somasundaram K, Son JH, Sonawane A, Song C, Song F, Song HK, Song JX, Song W, Soo KY, Sood AK, Soong TW, Soontornniyomkij V, Sorice M, Sotgia F, Soto-Pantoja DR, Sotthibundhu A, Sousa MJ, Spaink HP, Span PN, Spang A, Sparks JD, Speck PG, Spector SA, Spies CD, Springer W, Clair DS, Stacchiotti A, Staels B, Stang MT, Starczynowski DT, Starokadomskyy P, Steegborn C, Steele 
JW, Stefanis L, Steffan J, Stellrecht CM, Stenmark H, Stepkowski TM, Stern ST, Stevens C, Stockwell BR, Stoka V, Storchova Z, Stork B, Stratoulias V, Stravopodis DJ, Strnad P, Strohecker AM, Ström AL, Stromhaug P, Stulik J, Su YX, Su Z, Subauste CS, Subramaniam S, Sue CM, Suh SW, Sui X, Sukseree S, Sulzer D, Sun FL, Sun J, Sun J, Sun SY, Sun Y, Sun Y, Sun Y, Sundaramoorthy V, Sung J, Suzuki H, Suzuki K, Suzuki N, Suzuki T, Suzuki YJ, Swanson MS, Swanton C, Swärd K, Swarup G, Sweeney ST, Sylvester PW, Szatmari Z, Szegezdi E, Szlosarek PW, Taegtmeyer H, Tafani M, Taillebourg E, Tait SWG, Takacs-Vellai K, Takahashi Y, Takáts S, Takemura G, Takigawa N, Talbot NJ, Tamagno E, Tamburini J, Tan CP, Tan L, Tan ML, Tan M, Tan YJ, Tanaka K, Tanaka M, Tang D, Tang D, Tang G, Tanida I, Tanji K, Tannous BA, Tapia JA, Tasset-Cuevas I, Tatar M, Tavassoly I, Tavernarakis N, Taylor A, Taylor GS, Taylor GA, Taylor JP, Taylor MJ, Tchetina EV, Tee AR, Teixeira-Clerc F, Telang S, Tencomnao T, Teng BB, Teng RJ, Terro F, Tettamanti G, Theiss AL, Theron AE, Thomas KJ, Thomé MP, Thomes PG, Thorburn A, Thorner J, Thum T, Thumm M, Thurston TLM, Tian L, Till A, Ting JPY, Ting JPY, Titorenko VI, Toker L, Toldo S, Tooze SA, Topisirovic I, Torgersen ML, Torosantucci L, Torriglia A, Torrisi MR, Tournier C, Towns R, Trajkovic V, Travassos LH, Triola G, Tripathi DN, Trisciuoglio D, Troncoso R, Trougakos IP, Truttmann AC, Tsai KJ, Tschan MP, Tseng YH, Tsukuba T, Tsung A, Tsvetkov AS, Tu S, Tuan HY, Tucci M, Tumbarello DA, Turk B, Turk V, Turner RFB, Tveita AA, Tyagi SC, Ubukata M, Uchiyama Y, Udelnow A, Ueno T, Umekawa M, Umemiya-Shirafuji R, Underwood BR, Ungermann C, Ureshino RP, Ushioda R, Uversky VN, Uzcátegui NL, Vaccari T, Vaccaro MI, Váchová L, Vakifahmetoglu-Norberg H, Valdor R, Valente EM, Vallette F, Valverde AM, Van den Berghe G, Van Den Bosch L, van den Brink GR, van der Goot FG, van der Klei IJ, van der Laan LJW, van Doorn WG, van Egmond M, van Golen KL, Van Kaer L, Campagne $M$ van L, Vandenabeele $\mathrm{P}$, Vandenberghe W, Vanhorebeek I, Varela-Nieto I, Vasconcelos MH, Vasko R, Vavvas DG, Vega-Naredo I, Velasco G, Velentzas AD, Velentzas PD, Vellai T, Vellenga E, Vendelbo MH, Venkatachalam K, Ventura N, Ventura S, Veras PST, Verdier M, Vertessy BG, Viale A, Vidal M, Vieira HLA, Vierstra RD, Vigneswaran N, Vij N, Vila M, Villar M, Villar VH, Villarroya J, Vindis C, Viola G, Viscomi MT, Vitale G, Vogl DT, Voitsekhovskaja OV, von Haefen C, von Schwarzenberg K, Voth DE, VouretCraviari V, Vuori K, Vyas JM, Waeber C, Walker CL, Walker MJ, Walter J, Wan L, Wan X, Wang B, Wang C, Wang CY, Wang C, Wang C, Wang C, Wang D, Wang F, Wang F, Wang G, Wang HJ, Wang H, Wang HG, Wang H, Wang HD, Wang J, Wang J, Wang M, Wang MQ, Wang PY, Wang P, Wang RC, Wang S, Wang TF, Wang X, Wang XJ, Wang XW, Wang X, Wang X, Wang Y, Wang Y, Wang Y, Wang YJ, Wang Y, Wang Y, Wang YT, Wang Y, Wang ZN, Wappner P, Ward C, Ward DMV, Warnes G, Watada H, Watanabe Y, Watase K, Weaver TE, Weekes CD, Wei J, Weide T, Weihl CC, Weindl G, Weis SN, Wen L, Wen X, Wen Y, Westermann B, Weyand CM, White AR, White E, Whitton JL, Whitworth AJ, Wiels J, Wild F, Wildenberg ME, Wileman T, Wilkinson DS, Wilkinson S, Willbold D, Williams C, Williams $\mathrm{K}$, Williamson PR, Winklhofer KF, Witkin SS, Wohlgemuth SE, Wollert T, Wolvetang EJ, Wong E, Wong GW, Wong RW, Wong
VKW, Woodcock EA, Wright KL, Wu C, Wu D, Wu GS, Wu J, Wu J, Wu M, Wu M, Wu S, Wu WKK, Wu Y, Wu Z, Xavier CPR, Xavier RJ, Xia GX, Xia T, Xia W, Xia Y, Xiao H, Xiao J, Xiao S, Xiao W, Xie CM, Xie Z, Xie Z, Xilouri M, Xiong Y, Xu C, Xu C, Xu F, Xu H, Xu H, Xu J, Xu J, Xu J, Xu L, Xu X, Xu Y, Xu Y, Xu ZX, Xu Z, Xue Y, Yamada T, Yamamoto A, Yamanaka K, Yamashina S, Yamashiro S, Yan B, Yan B, Yan X, Yan Z, Yanagi Y, Yang DS, Yang JM, Yang L, Yang M, Yang PM, Yang P, Yang Q, Yang W, Yang WY, Yang X, Yang Y, Yang Y, Yang Z, Yang Z, Yao MC, Yao PJ, Yao X, Yao Z, Yao Z, Yasui LS, Ye M, Yedvobnick B, Yeganeh B, Yeh ES, Yeyati PL, Yi F, Yi L, Yin XM, Yip CK, Yoo YM, Yoo YH, Yoon SY, Yoshida KI, Yoshimori T, Young KH, Yu H, Yu JJ, Yu JT, Yu J, Yu L, Yu WH, Yu XF, Yu Z, Yuan J, Yuan ZM, Yue BYJT, Yue J, Yue Z, Zacks DN, Zacksenhaus E, Zaffaroni N, Zaglia T, Zakeri Z, Zecchini V, Zeng J, Zeng M, Zeng Q, Zervos AS, Zhang DD, Zhang F, Zhang G, Zhang GC, Zhang H, Zhang H, Zhang H, Zhang J, Zhang J, Zhang J, Zhang JP, Zhang L, Zhang L, Zhang L, Zhang MY, Zhang X, Zhang XD, Zhang Y, Zhang Y, Zhang Y, Zhang Y, Zhang Y, Zhao M, Zhao WL, Zhao X, Zhao YG, Zhao Y, Zhao Y, Zhao YX, Zhao Z, Zhao ZJ, Zheng D, Zheng XL, Zheng X, Zhivotovsky B, Zhong Q, Zhou GZ, Zhou G, Zhou H, Zhou SF, Zhou XJ, Zhu H, Zhu H, Zhu WG, Zhu W, Zhu XF, Zhu Y, Zhuang SM, Zhuang X, Ziparo E, Zois CE, Zoladek T, Zong WX, Zorzano A, and Zughaier SM. Guidelines for the use and interpretation of assays for monitoring autophagy (3rd edition). Autophagy 12: 1-222, 2016.

20. Klosowiak JL, Focia PJ, Chakravarthy S, Landahl EC, Freymann DM, and Rice SE. Structural coupling of the EF hand and C-terminal GTPase domains in the mitochondrial protein Miro. EMBO Rep 14: 968-974, 2013.

21. Kornmann B, Osman C, and Walter P. The conserved GTPase Gem1 regulates endoplasmic reticulum-mitochondria connections. Proc Natl Acad Sci U S A 108: 14151-14156, 2011.

22. Krebiehl G, Ruckerbauer S, Burbulla LF, Kieper N, Maurer B, Waak J, Wolburg H, Gizatullina Z, Gellerich FN, Woitalla D, Riess O, Kahle PJ, Proikas-Cezanne T, and Krüger R. Reduced basal autophagy and impaired mitochondrial dynamics due to loss of Parkinson's diseaseassociated protein DJ-1. PLoS One 5: e9367, 2010.

23. Kumar P, Henikoff S, and Ng PC. Predicting the effects of coding non-synonymous variants on protein function using the SIFT algorithm. Nat Protoc 4: 1073-1081, 2009.

24. Larsen SB, Hanss Z, and Krüger R. The genetic architecture of mitochondrial dysfunction in Parkinson's disease. Cell Tissue Res 373: 21-37, 2018.

25. Lee K-S, Huh S, Lee S, Wu Z, Kim A-K, Kang H-Y, and $\mathrm{Lu}$ B. Altered ER-mitochondria contact impacts mitochondria calcium homeostasis and contributes to neurodegeneration in vivo in disease models. Proc Natl Acad Sci U S A 115: E8844-E8853, 2018.

26. Lee S, Lee K-S, Huh S, Liu S, Lee D-Y, Hong SH, Yu K, and $\mathrm{Lu} \mathrm{B}$. Polo kinase phosphorylates Miro to control ERmitochondria contact sites and mitochondrial $\mathrm{Ca}^{2+}$ homeostasis in neural stem cell development. Dev Cell 37: 174-189, 2016.

27. Lek M, Karczewski KJ, Minikel E V, Samocha KE, Banks E, Fennell T, O'Donnell-Luria AH, Ware JS, Hill AJ, Cummings BB, Tukiainen T, Birnbaum DP, Kosmicki JA, Duncan LE, Estrada K, Zhao F, Zou J, Pierce-Hoffman E, 
Berghout J, Cooper DN, Deflaux N, DePristo M, Do R, Flannick J, Fromer M, Gauthier L, Goldstein J, Gupta N, Howrigan D, Kiezun A, Kurki MI, Moonshine AL, Natarajan P, Orozco L, Peloso GM, Poplin R, Rivas MA, RuanoRubio V, Rose SA, Ruderfer DM, Shakir K, Stenson PD, Stevens C, Thomas BP, Tiao G, Tusie-Luna MT, Weisburd B, Won H-H, Yu D, Altshuler DM, Ardissino D, Boehnke M, Danesh J, Donnelly S, Elosua R, Florez JC, Gabriel SB, Getz G, Glatt SJ, Hultman CM, Kathiresan S, Laakso M, McCarroll S, McCarthy MI, McGovern D, McPherson R, Neale BM, Palotie A, Purcell SM, Saleheen D, Scharf JM, Sklar P, Sullivan PF, Tuomilehto J, Tsuang MT, Watkins HC, Wilson JG, Daly MJ, and MacArthur DG; Exome Aggregation Consortium. Analysis of protein-coding genetic variation in 60,706 humans. Nature 536: 285-291, 2016.

28. Liu S, Sawada T, Lee S, Yu W, Silverio G, Alapatt P, Millan I, Shen A, Saxton W, Kanao T, Takahashi R, Hattori N, Imai Y, and Lu B. Parkinson's disease-associated kinase PINK1 regulates Miro protein level and axonal transport of mitochondria. PLoS Genet 8: 15-17, 2012.

29. Liu X, Wu C, Li C, and Boerwinkle E. dbNSFP v3.0: a onestop database of functional predictions and annotations for human nonsynonymous and splice-site SNVs. Hum Mutat 37: 235-241, 2016.

30. MacAskill AF, Brickley K, Stephenson FA, and Kittler JT. GTPase dependent recruitment of Grif-1 by Miro1 regulates mitochondrial trafficking in hippocampal neurons. Mol Cell Neurosci 40: 301-312, 2009.

31. Nemani N, Carvalho E, Tomar D, Dong Z, Ketschek A, Breves SL, Jaña F, Worth AM, Heffler J, Palaniappan P, Tripathi A, Subbiah R, Riitano MF, Seelam A, Manfred $\mathrm{T}$, Itoh $\mathrm{K}$, Meng S, Sesaki $\mathrm{H}$, Craigen WJ, Rajan S, Shanmughapriya S, Caplan J, Prosser BL, Gill DL, Stathopulos PB, Gallo G, Chan DC, Mishra P, and Madesh M. MIRO-1 determines mitochondrial shape transition upon GPCR activation and $\mathrm{Ca}^{2+}$ stress. Cell Rep 23: 1005-1019, 2018.

32. Nguyen TT, Oh SS, Weaver D, Lewandowska A, Maxfield D, Schuler M-H, Smith NK, Macfarlane J, Saunders G, Palmer CA, Debattisti V, Koshiba T, Pulst S, Feldman EL, Hajnoczky G, and Shaw JM. Loss of Miro1-directed mitochondrial movement results in a novel murine model for neuron disease. Proc Natl Acad Sci U S A 111: E3631E3640, 2014.

33. Nishida Y, Arakawa S, Fujitani K, Yamaguchi H, Mizuta T, Kanaseki T, Komatsu M, Otsu K, Tsujimoto Y, and Shimizu S. Discovery of Atg5/Atg7-independent alternative macroautophagy. Nature 461: 654-658, 2009.

34. Parekh AB and Putney JW. Store-operated calcium channels. Physiol Rev 85: 757-810, 2005.

35. Rakovic A, Ziegler J, Mårtensson CU, Prasuhn J, Shurkewitsch K, König P, Paulson HL, and Klein C. PINK1dependent mitophagy is driven by the UPS and can occur independently of LC3 conversion. Cell Death Differ 26: 1428-1441, 2018.

36. Reva B, Antipin Y, and Sander C. Predicting the functional impact of protein mutations: application to cancer genomics. Nucleic Acids Res 39: e118, 2011.

37. Saotome M, Safiulina D, Szabadkai G, Das S, Fransson A, Aspenstrom P, Rizzuto R, and Hajnoczky G. Bidirectional $\mathrm{Ca}^{2+}$-dependent control of mitochondrial dynamics by the Miro GTPase. Proc Natl Acad Sci U S A 105: 2072820733, 2008.
38. Sarraf SA, Raman M, Guarani-Pereira V, Sowa ME, Huttlin EL, Gygi SP, and Harper JW. Landscape of the PARKIN-dependent ubiquitylome in response to mitochondrial depolarization. Nature 496: 372-376, 2013.

39. Schwarz JM, Rödelsperger C, Schuelke M, and Seelow D. MutationTaster evaluates disease-causing potential of sequence alterations. Nat Methods 7: 575-576, 2010.

40. Shihab HA, Gough J, Mort M, Cooper DN, Day INM, and Gaunt TR. Ranking non-synonymous single nucleotide polymorphisms based on disease concepts. Hum Genomics 8: 11, 2014.

41. Sievers F, Wilm A, Dineen D, Gibson TJ, Karplus K, Li W, Lopez R, McWilliam H, Remmert M, Söding J, Thompson JD, and Higgins DG. Fast, scalable generation of highquality protein multiple sequence alignments using Clustal Omega. Mol Syst Biol 7: 539, 2011.

42. Stephen T-L, Higgs NF, Sheehan DF, Al Awabdh S, Lopez-Domenech G, Arancibia-Carcamo IL, and Kittler JT. Miro1 regulates activity-driven positioning of mitochondria within astrocytic processes apposed to synapses to regulate intracellular calcium signaling. J Neurosci 35: 15996-16011, 2015.

43. Treiman M, Caspersen C, and Christensen SB. A tool coming of age: thapsigargin as an inhibitor of sarcoendoplasmic reticulum $\mathrm{Ca}(2+)$-ATPases. Trends Pharmacol Sci 19: 131-135, 1998.

44. Vaccaro V, Devine MJ, Higgs NF, and Kittler JT. Miro1dependent mitochondrial positioning drives the rescaling of presynaptic $\mathrm{Ca}^{2+}$ signals during homeostatic plasticity. EMBO Rep 18: 231-240, 2017.

45. Valadas JS, Esposito G, Vandekerkhove D, Miskiewicz K, Deaulmerie L, Raitano S, Seibler P, Klein C, and Verstreken P. ER lipid defects in neuropeptidergic neurons impair sleep patterns in Parkinson's disease. Neuron 98: 1155.e6-1169.e6, 2018.

46. Vlahou G, Eliáš M, von Kleist-Retzow JC, Wiesner RJ, and Rivero F. The Ras related GTPase Miro is not required for mitochondrial transport in Dictyostelium discoideum. Eur J Cell Biol 90: 342-355, 2011.

47. Wang K, Li M, and Hakonarson H. ANNOVAR: functional annotation of genetic variants from high-throughput sequencing data. Nucleic Acids Res 38: e164, 2010.

48. Wang $X$ and Schwarz TL. The mechanism of $\mathrm{Ca}^{2+}$ dependent regulation of kinesin-mediated mitochondrial motility. Cell 136: 163-174, 2009.

49. Wang X, Winter D, Ashrafi G, Schlehe J, Wong YL, Selkoe D, Rice S, Steen J, Lavoie MJ, and Schwarz TL. PINK1 and Parkin target Miro for phosphorylation and degradation to arrest mitochondrial motility. Cell 147: 893-906, 2011.

50. Weihofen A, Thomas KJ, Ostaszewski BL, Cookson $\mathrm{MR}$, and Selkoe DJ. Pink1 forms a multiprotein complex with Miro and Milton, linking Pink1 function to mitochondrial trafficking. Biochemistry 48: 2045-2052, 2009.

51. Wüst R, Maurer B, Hauser K, Woitalla D, Sharma M, and Krüger R. Mutation analyses and association studies to assess the role of the presenilin-associated rhomboid-like gene in Parkinson's disease. Neurobiol Aging 39: 217.e13217.e15, 2016.

52. Yoshii SR, Kishi C, Ishihara N, and Mizushima N. Parkin mediates proteasome-dependent protein degradation and rupture of the outer mitochondrial membrane. J Biol Chem 286: 19630-19640, 2011. 
53. Zhang Y. I-TASSER server for protein 3D structure prediction. BMC Bioinformatics 9: 40, 2008.

Address correspondence to: Dr. Dajana Grossmann Luxembourg Centre for Systems Biomedicine (LCSB)

University of Luxembourg

7, avenue des Hauts-Fourneaux L-4362 Esch-sur-Alzette Luxembourg

E-mail: dajana.grossmann@uni.lu

Prof. Rejko Krüger Luxembourg Centre for Systems Biomedicine (LCSB)

University of Luxembourg 7, avenue des Hauts-Fourneaux L-4362 Esch-sur-Alzette Luxembourg

E-mail: rejko.krueger@uni.lu
Date of first submission to ARS Central, December 26, 2018; date of final revised submission, June 20, 2019; date of acceptance, July 12, 2019.

$\begin{aligned} & \quad \text { Abbreviations Used } \\ & \mathrm{CCCP}=\text { carbonyl cyanide } 3 \text {-chlorophenylhydrazone } \\ & \mathrm{DMEM}=\text { Dulbecco's modified Eagle's medium } \\ & \mathrm{ER}=\text { endoplasmic reticulum } \\ & \mathrm{EU}=\text { European Union } \\ & \mathrm{FBS}=\text { fetal bovine serum } \\ & \mathrm{LoF}=\text { loss-of-function } \\ & \mathrm{MCU}=\text { mitochondrial calcium uniporter } \\ & \mathrm{miRNA}=\text { microRNA } \\ & \mathrm{MiST}=\text { mitochondrial shape transition } \\ & \mathrm{O} / \mathrm{e}=\text { observed/expected } \\ & \mathrm{PD}=\text { Parkinson's disease } \\ & \mathrm{PE}=\text { phosphatidylethanolamine } \\ & \mathrm{pLI}=\text { probability of being LoF intolerant } \\ & \mathrm{PS}=\text { phosphatidylserine } \\ &\end{aligned}$

